\title{
Autobiographical Memory Narratives in Psychotherapy: A Coding System Applied to the Case of Cynthia
}

\author{
JEFFERSON A. SINGER ${ }^{\mathrm{a}, \mathrm{c}}$ \& LAURA BONALUME $^{\mathrm{b}}$
}

a Department of Psychology, Connecticut College

$\mathrm{b}$

Department of Psychology, University of Milan-Bicocca, Milan, Italy

${ }^{c}$ Correspondence concerning this article should be addressed to Jefferson A. Singer, Department of Psychology,

Connecticut College, 270 Mohegan Avenue, New London, CT 06320

Email: jasin@conncoll.edu

Acknowledgements: A large part of the work on this autobiographical memory narrative approach and the

development of this single case study took place over a visiting fellowship at Connecticut College, granted to Laura Bonalume by the doctoral program of the Department of Psychology, University of Milan-Bicocca. We are grateful to the following advisors, supporters, and departmental colleagues at the University of Milan-Bicocca: Margherita Lang, Laura Parolin, Angela Tagini, and Laura Rivolta. We especially acknowledge the Association for Research in Clinical Psychology (A.R.P., Milan) and its staff who provided the opportunity to conduct this analysis on an actual clinical case.

\begin{abstract}
Recent cognitive and psychodynamic oriented therapies have converged on the powerful role that narrative processing plays in psychotherapy. Although previous coding systems have examined specific aspects of memory narratives, there are no comprehensive methods for coding segments of clinical evaluations or psychotherapy sessions that zero in on the unit of a briefly recounted autobiographical memory narrative. The present single case study aims to introduce and to demonstrate the Coding System for Autobiographical Memory Narratives in Psychotherapy (CS-AMNP; Singer \& Bonalume, 2008) with a young female client whom we call "Cynthia." We applied this autobiographical memory narrative approach to the diagnostic interview of Cynthia in evaluation for psychotherapy and compared predictions based on its results to the clinician's report of Cynthia's actual therapeutic outcome. This study demonstrates the utility of the coding system for personality assessment and case conceptualization in the service of ongoing treatment. In addition, implications of this coding system for future research, clinical practice, and training are discussed.
\end{abstract}

Key words: autobiographical memory and psychotherapy; coding memories in therapy; memory narratives and therapy; case study; clinical case study

\section{CASE CONTEXT AND METHOD}

\section{A. Overview}

In recent decades, clients' narratives, collected during assessments and the course of psychotherapy, have attracted increasing scientific attention (Angus \& McLeod, 2004; Book, 2004; Boritz, Angus, Monette, \& Hollis-Walker, 2008; Siegel \& Demorest, 2010; Singer, 
Baddeley, \& Frantsve, 2008; White, 2004; White \& Epston, 1990). Each of these researchers and practitioners has argued that analysis of narratives can yield invaluable insights into individuals' efforts to create meaning and convey a coherent sense of unity and purpose in their lives (McAdams, 2001). The narrative units under scrutiny can come in many different formsfrom life narratives that encompass an individual's autobiography (Burns, 2001; McAdams, 2001; Singer, 1998) to brief cultural scripts that are more schematic than story-like (Luborsky \& Crits-Cristoph, 1998; White \& Epston, 1990).

This article highlights a particularly significant narrative unit for assessment and treatment in psychotherapy - the autobiographical memory narrative; and illustrates its use in the case of a client whom we will call "Cynthia." In a series of clinical case studies, Singer and colleagues (Singer, 1997, 2001, 2004, 2005, 2006; Singer et al., 2008; Singer \& Blagov, 2004; Singer \& Labunko-Messier, in press; Singer \& Salovey, 1993; Singer \& Salovey, 1996; Singer \& J. L. Singer, 1992) have illustrated how autobiographical memory narratives recounted by clients in psychotherapy can express central themes and conflicts, while simultaneously yielding salient metaphors and imagery that can serve as touchstones in the course of treatment. (Clinical examples from these studies are presented in Appendix 1.) In addition, these case studies have demonstrated how "affective scripts" (Demorest, 1995, 2007; Demorest \& Alexander, 1992; Siegel \& Demorest, 2010; Tomkins, 1979), identifiable across a series of memories, subsequently emerge in the transference relationship of client and therapist. Interpretations moving between narrative memories and the ongoing transference dynamic were shown to benefit the client's self-understanding and increased control over self-defeating patterns.

For example, Singer et al. (2008) describe the case of a middle-aged overweight man who recalled a series of memories that shared a common theme of humiliation by a critical mother and subsequent authorities in school, military, and work settings. These memories followed a repetitive narrative sequence in which an apparent triumph is undermined by a cruel remark or disdainful slight from a putative parental figure. Having identified this pattern through the collection of autobiographical memories, the therapist and client were able to isolate interactions in the therapy in which the same dynamic was enacted. In particular, they tracked exchanges in which the client experienced the therapist as falling short in offering a sense of nurturance and support for him as he struggled to overcome obstacles in his life. Therapeutic interventions drew on the vivid imagery offered by the narrative memories and their metaphoric meanings. For example, one of the client's memories recounted a time in which he was bitten by a crab at the seashore and his mother chose to laugh as he tried to free himself from its grip. Exchanges in which the client felt slighted or humiliated were thus dubbed moments when "the crab has gotten hold of you." This short-hand language served as a mutual touchstone for the client's affective script surfacing in the therapy or in other interactions in his life. Using this "emotional handle" (Greenberg, 2002), the therapist and client were able to devise cognitive-behavioral interventions that allowed the client to introduce self-talk and new behaviors that led to different endings to situations that would otherwise have repeated his familiar pattern of disappointment and humiliation. In other cases, clients have drawn upon their memory narratives as the sources of role-plays (Singer, 2004) or empathetic dialogues within a couple (Singer \& Labunko-Messier, in press), which have helped to encourage insight and behavioral change. 
If these autobiographical memory narratives can indeed serve a diagnostic and therapeutic function, both researchers and clinicians would benefit from developing a more systematic method for identifying, categorizing, and interpreting them in the course of assessment and treatment. Although previous coding systems have been employed for early memory assessment in the Adlerian tradition (Bruhn, 1990a, 1990b, 1992a, 1992b; Langs, 1965a, 1965b; Mayman, 1968) and for coding more general narratives or story-telling for relational themes and defensive structures (Angus \& McLeod, 2004; Book, 2004; Luborsky \& Crits-Cristoph, 1998; Siegel \& Demorest, 2010), there are no standardized methods for coding segments of clinical evaluations or psychotherapy sessions that zero in on the unit of a briefly recounted autobiographical memory narrative. Yet it is precisely these units across the course of a diagnostic interview or series of therapy sessions that can be extracted and assembled in order to determine an affective script that in turn often typifies the object relations and personality dynamics of the client in treatment.

In our laboratory work, we have defined a measurable memory unit, the self-defining memory, which consists of the following attributes; 1) vividness; 2) emotional intensity; 3) repetitively recalled; 4) linkage to memories that share similar thematic content; 5) connection to ongoing concerns or conflicts in the personality. Self-defining memories are a subtype of autobiographical memory narratives that have a particular thematic importance and are often touchstones for self-understanding and vehicles of communication about the self to others. Our own and others' studies have demonstrated a significant role for these memories in individuals' ongoing life goals and emotional experiences (Blagov \& Singer, 2004; Moffitt \& Singer, 1994; Singer, Rexhaj, \& Baddeley, 2007; Sutin \& Robins, 2005; Thorne, McLean, \& Lawrence, 2004; Wood \& Conway, 2006).

Singer and Blagov (2002; Blagov \& Singer, 2004) developed a reliable and valid coding system for self-defining memories, and this system has been utilized in clinical research (e.g., Jobson \& O'Kearney, 2006; 2008; Raffard, 2009; Sutherland \& Bryant, 2005). However, there is currently no clear method for identifying and coding these memories in psychotherapy assessment and/or psychotherapy. (One limited exception is a recent article by Boritz et al. [2008] that describes a partial use of the coding system to score memory specificity over the course of psychotherapy.) Although the case studies conducted by Singer have often relied on interpretations of self-defining memories that emerge in ongoing therapy, these case reports provide no systematic method for the collection, categorization, and analysis of these memories (see Singer \& Labunko-Messier, in press, for a recent exception).

The purpose of the current article is to introduce a formal system for coding all forms of autobiographical memory narratives in psychotherapy. The memory narrative coding system elaborated in this paper allows one to determine the presence or absence of autobiographical memory narratives in the client's discourse with the therapist. Once autobiographical memory narratives are identified, they can be coded for the specificity of their structure and for their degree of meaning-making or integration with the larger self-concept (Blagov \& Singer, 2004; Singer \& Blagov, 2002). The memory narratives as a whole can be examined for similarity of affective sequence, repetition of archetypal characters, recurrent defenses, and overlapping 
relational dynamics. Finally, a scriptal pattern or template can be extracted that captures a selfdefining theme or conflict for the client.

To demonstrate how the system works and to illustrate its potential utility in assessment of clients in treatment, we present a case study of Cynthia. Drawing on the transcripts of her psychological assessment over a series of meetings, we extracted, coded, and interpreted the autobiographical memory narratives that emerged from her dialogue with the clinician. Based on this memory analysis, we derived a series of predictions for how the psychotherapy would proceed. To explore the utility of our coding system, we examined the accuracy of our predictions against the actual outcomes, as described by an independent clinician who served as Cynthia's therapist over the course of treatment. The article concludes with some general observations and recommendations regarding the future use of the memory narrative coding system.

\section{B. Goals of the Present Case Study}

The present single case study is part of a larger sample of 30 clients, who attended a diagnostic consultation at the "Association for Research in Clinical Psychology" (A.R.P.) in Milan, Italy. Drawing on a particular client from this group, "Cynthia," we sought to accomplish the following goals through the coding of her autobiographical memory narratives:

- Reliably identify spontaneous autobiographical narratives in the flow of a clinical interaction;

- Distinguish autobiographical memory narratives from general autobiographical knowledge

- Analyze in detail the narrative memories' structure, meaning-making, and relevant themes for a clearer understanding of such memory content dimensions as emotion scripts, wishes, fears, expectations, defenses, relationship representations, beliefs, and unresolved issues which contribute to the client's personality and potential diagnosis

- Generate predictions about the course of psychotherapy, including major issues to emerge, likely resistances, and the pattern of therapist-client interactions.

\section{THE CLIENT}

Cynthia is a cooperative and amicable 19-year old female adolescent. Even with her "punk" attire and her "rasta" hair-style of dreadlocks, she looks like a shy teenager. At the time of the interview, Cynthia was living with her sister and studying art at an urban university in Italy, far from her family home in a more rural community. In her presenting complaint, she expressed anxiety and strong social inhibition that prevented her from sharing easy relationships with others and also interfered with her academic and career ambitions. She felt afraid and scared in nearly all social contexts. She described having "panic attacks" with physical sensations such as sweating and heart racing, while she had periods of derealization and debilitating fear ("On 
the subway I'm not able to sit and to read; If I try to read, then I'll get very agitated... I don't know where to look, how to stay seated calmly...”).

Cynthia comes from a mixture of aristocratic and more middle class backgrounds. Her mother grew up in a titled family with large land holdings in the Northern Italian countryside. From an early age, Cynthia was exposed to the stories of her noble origins and the aristocratic lifestyle of her maternal grandparents. Her father had more modest roots, based in the building trades, and ended up becoming a civil engineer. Cynthia's mother was always the primary caretaker for the children and never worked outside the home. Cynthia has two older siblings, the sister with whom she is living and a brother who continues to live near their parents. The brother is currently struggling with a substance abuse problem. Cynthia recalls her upbringing as difficult due to her mother's frequent bouts of anger, series of somatic complaints, and constant relational difficulties.

\section{GUIDING CONCEPTION}

The "Association for Research in Clinical Psychology" (A.R.P.) program in which Cynthia participated as a client is a heavily diagnostic- and assessment-based approach that combines a relational psychoanalytic perspective with cognitive-behavioral techniques and psychopharmacological interventions. Its therapists are a mix of psychologists, social workers, and psychiatrists. Clients range in diagnoses from major mood disorders to personality disorders to adjustment disorders. The initial diagnostic period of the treatment can last 2-3 months and typically includes extensive psychological assessment with a variety of objective and projective tests, conducted by other clinicians within the program. At the end of this assessment period, the clinical team creates a case formulation and provides feedback interviews to the client. Weekly psychotherapy continues after this feedback with stipulated goals relevant to the diagnostic formulation. Although cognitive-behavioral techniques, such as cognitive re-structuring, imagery, and homework assignments may be employed, the overarching emphasis is on the therapeutic alliance and relational dynamics that emerge in the treatment. Usually, treatment does not extend beyond two years of weekly sessions. Due to the strong presence of psychiatrists in the A.R.P. program, psychopharmacological interventions are not uncommon.

\section{ASSESSMENT OF THE CLIENT'S PROBLEMS, GOALS, STRENGTHS, AND HISTORY}

\section{Overview of the The A.R.P. Assessment Process}

The A.R.P. assessment protocol consists of an initial clinical screening interview, followed by two or three comprehensive history-taking sessions (the biopsychosocial interview) and a battery of tests (cognitive tests, projective tests, and personality inventories). The biopsychosocial interview is composed of five relevant sections, including: (1) family history; (2) client's life history; (3) client's academic history and job career; (4) sexuality and romantic relationships; and (5) history of psychological difficulties and/or disorders. 
Clients are encouraged to recall experiences from childhood and adulthood, while reflecting on experiences associated with trust, mentoring, and positive peer and romantic relationships across their lifespan. Interviewers are trained to attend to the clients' emotional responses around narrative material and to follow up with questions that offer opportunities to make connections across powerful episodes from their lives. In the spirit of Sullivan's (1954) classic psychiatric interview, the goal of the biopsychosocial interview is to create a dynamic within the dyad that allows for learning and insight to be transmitted in both directions. Clients should leave the assessment sessions feeling that they have not simply given information to be formulated by the diagnostic team, but that they have come away with greater understanding and awareness of themselves.

Prior to Cynthia's case study, the interviewer, blind to the aim of the study, had received specific training in the biopsychosocial approach and was required to fill out a structured form covering the full range of material to be obtained. Training was provided by a senior expert clinician who had ten years of practice with this interview approach.

The interviewer who met Cynthia twice for the detailed interviews was a female doctoral student in clinical psychology. Prior to the study, she had had two years of training and practice as an A.R.P. interviewer; and she had been a main person in administering the biopsychosocial interviews and the other assessment tests in the A.R.P. program. After the assessment process, a different staff member became Cynthia's therapist.

\section{Specific Coding of Cynthia's Autobiographical Memory Narratives from the Biopsychosocial Interview}

The major goal of this project was to demonstrate that a meaningful assessment of Cynthia could be derived from an analysis of Cynthia's autobiographical memory narratives evoked over the course of the biopsychosocial interview. To pursue this goal, we developed a manual for identifying and classifying her memory narratives, The Coding System for Autobiographical Memory Narratives in Psychotherapy (hereafter called the CS-AMNP, Singer $\&$ Bonalume, 2008). The various components of the CS-AMNP are outlined in Figure 1.

In the following, we will describe each component of the CS-AMNP, and then describe our analysis of Cynthia's interview material from the perspective of that component.

\section{Introduction to the CS-AMNP}

Despite the power of personal memory narratives to provide insight into the self's most salient concerns, individuals often find ways to describe their lives and experiences in terms that do not generate the specific imagery and emotional intensity of these memories. Individuals speak about life events in more general summarized language, avoiding reference to specific identifiable moments in time. Similarly, individuals can provide unadorned facts, statistics and descriptions that characterize people, events, or time periods without filling in the sensory and emotional immediacy of a specific recollection. Individuals can often speak about historical events or incidents in the lives of other people; they can detail the plots of novels, films or plays. Although all of this information may be useful for therapeutic consideration, and some of it may 
be organized in a narrative structure, none of it approaches the revelatory quality and significance of specific personal memory narratives (Angus, Lewin, Bouffard, \& RotondiTrevisan, 2004). Even when individuals are disclosing autobiographical narrative material, there is still a difference between accounts of recent events that have yet to be fully processed and linked to the long-term self and events from the past that have been rehearsed and embedded in the long-term self's network of goals, meaning systems, and affective associations (Conway, Singer, \& Tagini, 2004; Singer \& Conway, in press). The CS-AMNP helps the practitioner make these useful distinctions between narrative and non-narrative material, between autobiographical and non-autobiographical narratives, and between present and past autobiographical narratives.

Specifically, as outlined in Figure 1:

Step 1 (Topic Definition) divides the therapy transcript into discrete topic segments in order to isolate distinct narrative units; this process avoids overlaps or repetitions in coding.

Step 2 (Narrative Complexity Coding) offers a method for distinguishing defined narratives within topic segments. Narrative units that receive scores below 3 on narrative complexity are too fragmented or discursive to be considered for further memory coding.

Step 3 (Defining Autobiographical Memory) identifies narrative units which are 3 or greater in complexity (from Step 2), which concern events that happened at least one year ago, and which were witnessed or experienced by the client first-hand. Narrative units that meet these criteria are considered autobiographical memory narratives and can be assessed for additional characteristics. Note that a score of 3 or better on narrative complexity assures that the narrative unit has some semblance of temporal or causal sequences as well as possible information about outcome - these are critical dimensions of interpretable narratives. The stipulation of one-yearold is to ensure that the memory narrative has had time to connect to the enduring meaning and affective networks of the long-term self. The requirement that the event has been personally experienced is to ensure what Tulving refers to as an "autonoetic quality" to the memory - it is a recollection that belongs in sensory quality to the self rather than something one has been told or learned only indirectly (Wheeler, Stuss, \& Tulving, 1997).

Steps 4 and 5 (Coding for Specificity and Integration) draw on the Singer and Blagov (2002) coding manual for self-defining memories. Specificity coding identifies the memory structure as specific or summary in nature; and as we elaborate later on, these structural differences have implications for personality and defensive styles. Integration coding identifies the degree to which the client has linked the content of the memory to more longstanding concerns of the self. As we shall see, this tendency toward integration is linked to psychological adjustment, impulse control, and insight.

Steps 6 and 7 (Thematic Analysis and Affective Scripts) connect the content and sequence of emotions in the narratives across all of the memory units in order to look for patterns of defenses, object relations, and affect regulation. These steps allow us to extract metaphors and recurrent themes that are likely to be useful in transference interpretations. 


\section{$\underline{\text { The Detailed Coding System }}$}

A detailed description of the 7 steps of the CS-AMNP coding system are presented in Appendix 2. Where available, examples are provided from Cynthia's case.

\section{Coding Results and Interpretation for Cynthia's Material}

\section{Step 1. Topic Definition (see Figure 1 and Appendix 2)}

Looking at Cynthia's transcripts, we subdivided her two verbatim interview texts into 75 topic segments according to the guidelines stipulated above. All segments were classified with a label according to its most prominent topic, as in the following example:

[tense change - Segment 43 - mother's grandmother in Cynthia's childhood] A very important thing that I remember about my mother's grandmother is that they made me kiss her, even though I did not want to - "Kiss your grandma!" you know... and I said "Why should I? Why do I have to make such a big deal? I want to play..." ... They made me ... unwillingly. [shift- end Segment 43]

\section{Step 2. Narrative Complexity Coding (see Figure 1)}

All segments were coded according to the 5-point scale of "narrative complexity." Descriptions with low levels of narrative complexity were most prevalent. As shown in Figure 2, Cynthia tended to tell stories that were below a level 3 complexity rating, reflecting confusing stories without defined outcomes and obvious causal sequences. Her speech was sometimes slow and fragmented, and her narrative style, repetitive. Specifically, as Figure 2 indicates, Cynthia produced 34/75 (45\%) narrative segments at the lowest level of complexity and only 10/75 $(13 \%)$ at the highest level of complexity. When we looked at the total narrative segments that were at 3 or below in complexity, 56/75 (75\%) met these criteria (see Figure 2). These results suggest that Cynthia often produced disjointed and fragmented memory narratives, indicating an overall lower level of ego development and a less coherent narrative identity.

Previous research on narrative complexity involving "nuclear episodes" has shown that effective causal and temporal linkages and density of narrative structure (cf. Labov, 1997) are correlated with ego development, as measured by the Loevinger Sentence Completion Test (McAdams, 1988). As a late adolescent, according to Bluck and Habermas (2000), Cynthia should have achieved a greater degree of temporal and causal coherence in her narratives. These difficulties with narrative coherence indicate that she remains in a formative state of identity consolidation; her capacity for both cognitive and affective regulation is still developing.

\section{Step 3. Defining Autobiographical Memory (see Figure 1 and Appendix 3)}

All 75 of Cynthia's narrative segments were evaluated for their depiction of a personally experienced event that took place at least 12 months ago. After review by two raters, 24 episodes $(32 \%)$ that qualified as autobiographical memory narratives were extracted from the 75 narrative segments. These 24 memory narratives are the major units that we worked with in 
subsequent analyses that allow for critical interpretation of Cynthia's autobiographical memory narratives.

\section{Step 4. Scoring the Memory Narratives for Specificity (see Figure 1)}

Using the Classification System and Scoring Manual for Self-defining Memories (Singer $\&$ Blagov, 2002), we next coded the 24 memories for specificity and meaning integration. Cynthia displayed a powerful tendency to overgeneralize in her memories, producing only 4/24 specific memories (16.7\%). (These four are listed in Table 1.) She recalled an unusually high number of generic memories (blending similar events separated by large units of time into one summarized memory) - 11/24 (45.8\%) (see Figure 3). Based on our laboratory research (Blagov \& Singer, 2004; Moffitt \& Singer, 1994; Singer \& Moffitt, 1991-92), the usual ratio of specific to summary memories is roughly 80 to $85 \%$ specific vs. 20 to $15 \%$ summary.

In an interview setting, it would not be uncommon for clients to answer with generalized responses to questions about important figures or time periods in their lives, but most clients, in our clinical experience, follow up the generalization with a more specific incident or example. Cynthia had difficulty moving to this level of detail and her narratives of her experiences would often fragment before she could reach a specific remembered incident. For example,

\section{[Segment 13]}

Cynthia: Maria, my mother's grandmother, was a weird character in the family because...well, she was an old-style countess with overly romantic stories. She made me long for and dream about her tales of carriages and noble parties. It was really another time period - the old days she recalled, but her relationship with me was distant... we played cards, other games, but she never touched me, never showed any real human feelings, just many stories.

\section{Clinician: Say more....}

Cynthia: Perhaps she came from another era, another time, another context. She needed to tell us all that stuff. Anyway, her stories were really interesting, even though I was just a child.

Based on previous research, which has demonstrated a correlation between higher numbers of summary memories and defensiveness, as measured by the Weinberger Adjustment Inventory - Short Form (Blagov \& Singer, 2004), Cynthia's memory narrative data suggest a defensive style that allows her to control recall of specific memories that might be too vivid and emotionally painful to re-experience. Drawing more general pictures, particularly of her mother's negative and isolating behavior, may buffer Cynthia from having to "see and hear" past conflicts and anxiety-provoking interactions.

Interestingly, Cynthia's four specific memories, listed in Table 1, are all negative, and three of the four memories involve struggles of will or threatened autonomy. 
- Specific Memory 1. The earliest and perhaps least threatening of the memories involves her refusal to comply with a request to give her grandmother a polite kiss. She tells her family that she would rather play with her toys.

- Specific Memory 2. The next specific memory from her elementary school years concerns her mother's decision to send her to a psychologist after she had refused to go to school several times. She tells her mother that she is not crazy, but her mother insists on sending her anyway.

- Specific Memory 3. The third memory focuses on how her friends talked her into choosing a more traditional school for high school instead of the art school that she had first thought to attend. Later that same day at dinner she recalled arguing with her mother to allow her to apply to this school. She indicates that she later regretted this decision and the fact that she let her friends influence her.

- Specific Memory 4. The last specific memory captures her mother's troubled relationships with family members. She recalls overhearing her mother and aunt yelling at each other. Her mother was defending herself and claiming that the aunt's husband had raped her, while the aunt was insisting that Cynthia's mother had seduced him. Cynthia explained that this fight held the key to why her mother and aunt had not been on speaking terms for many years.

In all four of these memories, the notion of individual will asserted toward a positive end is undermined at multiple levels. In the first memory, Cynthia's refusal to show respect to her grandmother has a streak of independence, but also of petulance in it. She is not necessarily proud of her assertiveness in that situation. In the second, school refusal memory, Cynthia's willfulness has led her mother to question her mental health, and her choice to avoid school has a clearly self-sabotaging dimension. In the third memory about her high school choice, Cynthia also describes a contested sense of autonomy; she is swayed to a decision about which she has later misgivings, but stubbornly argues its merits when challenged by her mother. Finally, the last memory of her mother's and aunt's confrontation hinges on the question of whether her mother's sexual breach with her uncle was willingly committed or forced.

The confluence of these four specific memories that reflect Cynthia's ambivalence about self-assertion indicate that this agentic theme (see Appendix 2, Step 6) is highly active in her consciousness and one that she is willing to engage and question at this point in her development. On the other hand, interpersonal memories related to her struggles with connection to others, whether her immediate family or peers, are uniformly generic and kept at a degree of distance. It leads us to surmise that there is more stark pain associated with the sense of isolation and alienation that she has often felt in her relations with her mother, as well as with schoolmates. She keeps these communal memories (see Appendix 2, Step 6) at a more abstracted distance to regulate the emotional intensity brought on by specific recollections of these relational disappointments. On the other hand, she is more willing to engage with themes of rebellion, resistance, and self-assertion with both positive and negative consequences. 
Step 5. Scoring the Memory Narratives for Integration (see Figure 1)

Turning to evidence of her integrative efforts to make meaning of her memory narratives, Cynthia showed little inclination to step back from her memory narratives in the initial assessment sessions. She generated only $3 / 24$ (12.5\%) integrative memory narratives, compared to a range of 20 to $40 \%$ found in late adolescent and young adult samples (Blagov \& Singer, 2004; Thorne, McLean, \& Lawrence, 2004) (see Figure 4).

Cynthia's three integrative memories are listed in Table 2. All illustrate her perception of how certain life experiences have pushed her to develop protective defenses of escape and rationalization.

- Integrative Memory 1. In her first integrative memory, Cynthia explains that she is willing to go out alone rather than call someone whom she does not value simply for the sake of company. She expresses the lesson, "Better to be alone than in bad company." However, she acknowledges that adhering to this life lesson has only increased her isolation from others.

- Integrative Memory 2. This memory gathers together examples of how Cynthia's mother complains about physical ailments (that may or may not be real) as a way to hide her disappointment with others and justify her isolating tendencies.

- Integrative Memory 3. The third integrative memory again echoes a theme of escape into art and imagination as a respite from feelings of inadequacy. Cynthia had started painting all the way back in nursery school, but often doubted her ability, together with doubting her physical appearance and self-worth. As Cynthia grew older, she told herself that artists, writers, and musicians were gifted people, beautiful in their work, and also in their personages. She tried to persuade herself that by being a talented artist, her physical beauty would emerge as well.

Similar to the pattern in her summary versus specific memories, Cynthia's efforts at integration coalesce around the general problem of how a sense of inadequacy engenders social withdrawal and leads to defensive justifications for avoiding attachment. Her meaning-making efforts are explorations in explaining to herself her own and her mother's behaviors that seem to lead to limits on their social interaction. With specificity and integration examined, we are ready to pull together thematic patterns across the entire set of memories.

Step 6. Thematic Analysis involving Contamination Sequences (see Figure 1 and Appendix 2)

As described in Appendix 2, redemption sequences begin with negative events that center on struggles, obstacles, and setbacks, but end with moments of triumph, growth, rejuvenation, and positive emotion; while contamination sequences begin with hope or positive circumstances and end in frustration, disappointment, and dejection. Overall, Cynthia's memories were dominated by her struggles with anxiety, isolation, and alienation along with negative themes of her mother's destructive behavior. Out of her 24 memories, there were no discernible redemption 
sequences and there were $6(25 \%)$ contamination sequences. This pattern certainly confirms her current depressive state and struggle with any sense of positive well-being. There were only two memories that could be characterized as mostly positive - one regarding her recollections of her father's "level-headed" temperament, and the other of the warmth and kindness of her paternal grandmother. In contrast, here is a representative contamination memory:

...the first six months [at high school] everything went well. I studied; I wanted it to go well. I was motivated. Then the teacher...was replaced. I lost this person whom I liked a lot and I let everything go bad. Only at the end I raced to improve some of my grades to try to finish well.

...I also was not satisfied with my relationships. I had expected that going to school in a bigger city would be better. And it was always the same, the small town girl in a city, studying something that I didn't understand and then when my teacher left...I remember all the endless afternoons in front of the T.V., eating chips. It was terrible. I was trying to lobotomize myself, anything not to study.

Above and beyond these contamination sequences, her memories are dominated by the depiction of her combative, perhaps even slightly paranoid, mother, acting in alienating and damaging ways. In 13/24 memories (54\%), Cynthia describes her mother as volatile in emotion, self-centered, and generating extreme conflicts with her father, siblings, and relatives. Her mother emerges across the memories as a narcissistic individual who will engage in manipulative and even compromising activities that allow her to achieve her own ends. These memories suggest a fundamental distrust that Cynthia feels in her most important caretaker's ability to be a reliable source of nurturance and guidance. At her worst, her mother looms as an actual threat and danger to Cynthia's psychological and perhaps even physical integrity.

Cynthia recounts memories of her mother kicking her father and sister out of the house and refusing to reconcile with them. She offers memories of her mother's manipulative behavior in order to get her way and control others. She told one memory of her mother planting a bottle of wine on a teacher during her own high school years in order to get him brought up on charges of corruption for accepting inappropriate gifts from students. She describes how her mother claims a variety of physical ailments as a way to avoid social obligations, but refuses to see any kind of physician for treatment. In a set of particularly troubling memories for Cynthia, she explains how her mother and her father's sister who used be close friends no longer talk to each other. Although she kept the reason for this feud secret from Cynthia for many years, it finally came out that the aunt had accused her mother of sleeping with her husband. In turn, her mother vehemently denied any responsibility and claimed that the sister's husband had raped her. Most importantly, Cynthia depicts her mother in gross denial of any accountability for the emotional conflicts and rejections she experiences. Her mother walls herself off in the large ancestral home of her family and increasingly isolates herself from other family members. The following memory captures vividly how Cynthia experiences her current relationship with her mother,

...The real crisis and traumatic moment came five years ago...My parents had a severe rift...frequent fights; they talked about divorce. My father rented a flat and in one of these fights she saw that her children were opposed to her. They tried to explain where they saw 
her at fault, but I don't know that she could see this. I don't think she understood that we would not support everything she did just because she was our mother. We were able to think for ourselves. And so - Betrayal! ...My relationship with her has never had a major crisis, but slowly I have been feeling more alone and have closed myself off from anything to do with her - no interaction and no contact.

$\underline{\text { Step 7. Affective Scripts (see Figure 1) }}$

The above memory ends in relational distance and isolation. Unfortunately, this pattern has become a pervasive affective script for Cynthia as well. Repeating her mother's behavior, she has internalized the defensive and affective regulation strategy of social withdrawal. When confronted with interpersonal challenges or difficulties, she retreats from the world and withdraws from contact with family, friends, peers, or authorities. During these periods of removal from social interaction, she relies on art, her imagination, and her aristocratic fantasies to provide solace and a direction for her energy and desire. She can also, paralleling her mother, act out in rebellious/destructive ways or somaticize. The affective sequence within her script can be schematized as:

\section{Social Threat $\rightarrow$ Imagined Rejection $\rightarrow$ Mixture of Hurt, Anger, Pride $\rightarrow$ Acting Out and Isolative Withdrawal $\rightarrow$ \\ Retreat into Art, Imagination, and "Old World" Fantasies}

Much of this pattern can be traced to the friction between her family's aristocratic background and the modest circumstances of most of the townspeople of her community. She recalls being called "little countess" by the other children, always feeling different and isolated in her palatial home. She described herself as

...missing real contact with other children, with the real world...I couldn't go out with other peers, or just play with the neighbors, the way the other kids usually did every day. Then

there was all this pressure about family memories and stories - all the old stuff around me, stories about events they told me that... are like dreams to me. I have never been able to live these things; I have never lived them, but I have to remember them.

In another memory, she explains how her mother's grandmother would fill her with "overromantic stories that she would long for and dream about, her tales of carriages and noble parties..." In the same memory she points out how their relationship was distant, that she "never touched me...[showed] no human feelings." It is as if Cynthia has access to an ethereal fantasy, "noble" but removed from physical reality.

In a memory several years later, during her high school years, Cynthia again felt socially different, almost for the opposite reason from her early youth. Although she may have been perceived as too "elegant" in her small town, she found herself more liberal and free, compared to the highly regimented and restricted behavior exhibited by her peers in the "classical" high school she attended. Once more she felt alienated from her peers and cut off from the mainstream. 
In all, 12 of the 24 memories (50\%) explicitly convey an affective sequence in which the main protagonist of the memory (either her mother or herself) experiences some form of social rejection, whether imagined or actual, and responds with withdrawal from contact and engagement in an isolative activity. Here is an example of this affective script for her mother:

Clinician: [Did your mother feel] jealousy toward your mother's sister?

Cynthia: Yes...They have refused to talk for years and years.

Clinician: For that long! Do you have a memory of this?

Cynthia: They had a brief period of reconciliation and that ended about two years ago. However, since I was a child I have never seen... so it's hard for me to remember; we haven't had any contact; we have lived close, but...

Clinician: Side by side?

Cynthia: Yes, yes, yes, but so separated.

In a similar vein, we can return to Cynthia's memory of her feigned sickness as a way to avoid a strict teacher at school:

I liked knowing new people.... and then a black hole. I didn't want to go to school...I warmed up a thermometer over a light bulb and my mother after awhile... after many physical examinations sent me to a psychologist...but I didn't want to go school...perhaps it was due to having a too strict teacher... who didn't fit the image of a teacher that I held inside, someone easier, but I think that shouldn't warrant...it wasn't a valid reason to pretend to be sick... and my mother never knew the truth.

Now as a young adult, Cynthia is again repeating this pattern of isolation despite the anxiety it causes:

I want to enjoy my independence in Milan, but also I don't like to be with people without a sense of mutual understanding and esteem. I usually wouldn't call someone I didn't really like just to have some company. I agree with the idea "better alone than with someone who is not good company," but this idea makes me more isolated. So I don't want to call someone, but I would like to go out alone without feeling any concerns...

Associated with Cynthia's choice of social withdrawal is her strong investment in her imagination. In the memory of being forced to kiss her grandmother, she wants to be left alone to play. In another memory, she describes her mother as behaving like a "monster" in fights with her father and her siblings, but then mentions that she would resort to play based in her own imagination, while losing herself in the large garden of their home. In another memory, she indicates that she created a mythology for herself (in which she no longer believes) that by being an artist and creating beautiful works, it would make her beautiful as well. In several other memories, she mentions her desire to paint and to attend the art school that she eventually transferred to after beginning in the classical school. 
A final theme that emerges across the memories for Cynthia is the loss of positive adult figures in her life. She reserves some of her most positive and loving terms for her father's grandmother who passed away when she was still a child. She describes her father in very loving and respectful terms, but recalls him being chased out of the home by her mother. She recalls the psychologist with whom she met after her school refusal in a positive manner, but then depicts him as fading out of her life. Finally, she mentions losing her favorite teacher in high school, leading to a period of social rebellion and alienation. Across the 24 memories, there are no sustained or enduring positive relationships with older adult figures. Similarly, there are no lasting friendships with peers. Only her siblings seem to hold a consistent and benign role in her life, but she provides minimal detail about her relationship with them.

\section{FORMULATION AND TREATMENT PLAN BASED IN THE MEMORY ANALYSIS}

\section{Formulation}

Coding and analysis of Cynthia's 24 narrative memories has yielded an informative picture of her personality dynamics, cognitive complexity, primary defenses, and affective regulatory strategies. As we pull together an integrated portrait of these dimensions, we emerge with a series of predictions about Cynthia's interpersonal tendencies and likely transference responses in the course of psychotherapy.

Cynthia's structural approach to narrating her memories revealed relatively low levels of narrative complexity and memory specificity. Her inability to recount narratives from her life with orderly sequences, causal and temporal coherence, and defined outcomes suggests a delayed level of ego development and impulse control. She experiences her past as a pastiche of fragmented images and impressions. There is little sense of an "authored" past; instead past experiences seem to invade and inhabit her memory with vague and ominous intrusions. The narratives lack nuance and tend toward "black and white" categorizations.

In particular, she had great trouble communicating about familial and peer interactions with any kind of specificity and emotional immediacy. Relying on summary memories, she seemed to distance herself from a series of painful and conflictual interpersonal encounters. This was particularly true of her mother, but she also conveyed a consistent sense of alienation and distance with regard to school classmates and potential childhood playmates. Her strong inclination to eschew specific incidents, dialogue, and emotional responses in her narrative memories suggests a tendency toward repressive-defensiveness and intellectualization (see Blagov \& Singer, 2004). Combined with her limited range of ego development, her defensive profile points to an individual who is avoidant, emotionally restricted, cognitively rigid, and likely to escape from social interaction into fantasy, abstraction and self-defeating acts of rebellion.

These limited and immature defenses and affect regulation strategies have resulted in a sense of thwarted agency and self-development. This arrested growth is reflected in the dearth of meaning-making and lesson-learning that she was able to extract from her narrative memories. 
She was able to step back and make integrative statements about only 3 of her 24 memories. These statements overlapped in their emphasis on the use of rationalization and artistic fantasy to escape the threat of painful social interaction. Able to see how her current defenses lead to isolation, she has yet to generate a more constructive coping strategy to counteract this pattern. It is not surprising then that the complex challenges of attending university in a large urban center have led to increasing anxiety and panic attacks. Her sense of agency and capacity for controlled and planful action appear to be stunted, leading to impulsive and self-destructive responses to her social anxiety.

Turning to the thematic strands that run across the entire set of the memories, Cynthia expresses little positivity or redemptive spirit in her narratives. There is a strong representation of contamination sequences in which potentially good experiences turn sour or transform into more unhappy and alienating events. Coloring the majority of her narrative memories is the malevolent dark cloud of her mother, who is portrayed as overbearing, paranoid, vainglorious, manipulative, and threatening. Sequestered and isolated in her palatial ancestral home, she complains of ill-defined physical infirmities and repels any positive social contact.

Despite Cynthia's repugnance in response to her mother's destructive behavior, she has internalized some of these self-defeating and isolative tendencies. When confronted with threatening or unfamiliar social interactions, Cynthia is likely to withdraw, expressing themes of indifference and alienation. She escapes to her imaginative world of art and also takes refuge in the romanticized past of her aristocratic ancestry. These are safer alternatives to aggressive or rebellious tendencies, the latter manifest in her "punk" wardrobe and her acts of graffiti during high school. It is likely then that she will display this affective script of social threat- - hurtangry-prideful responses followed by social withdrawal into art and fantasy-in future social encounters and perhaps even in the transference relationship that she develops with a therapist.

\section{Implications for a Treatment Plan}

As mentioned earlier, Cynthia's actual therapy at the A.R.P. clinic in Milan was an integrated treatment approach that blended cognitive and psychodynamic concepts, supported by psychopharmacological interventions. The A.R.P. is unique in its emphasis on an extended and comprehensive diagnostic component of treatment. The initial history can last over several sessions, and even after the client has begun weekly therapy with an assigned clinician, objective and projective testing by other members of the clinical team will continue. As the team formulates an overall understanding of the client's diagnosis and treatment objectives, the primary therapist provides feedback to the client and these feedback sessions are considered a critical component of the ongoing treatment. This assessment and formulation phase of treatment can last well into the first six months of treatment. Most of the therapists have training in a relational/object relations perspective on psychotherapeutic dynamics and there is an overall emphasis at A.R.P. on careful attention to transference and the development of trust in the alliance. At the same time, the clinicians have received training in and apply cognitive techniques of re-framing, thought disputation, and mental imagery. 
Given this therapeutic approach and the two year time frame favored by the clinic, we highlight the following considerations in a proposed course of treatment for Cynthia. From a relational standpoint, the therapist has a potentially rich set of images and metaphors to serve as "emotional handles" or touchstones of communication with Cynthia over the course of treatment. In addressing Cynthia's fear of social interactions, the therapist can help her explore her persona as the "little countess" who feels odd or different from her peers. In the therapeutic relationship, the therapist can help Cynthia bring to light her fear of being disappointed by authority, and even worse, the possibility that a parental figure will abandon her or turn against her. As her trust in the therapy deepens, the therapist could reinforce her ongoing efforts to build a positive sense of agency that allows for self-assertion and the pursuit of her artistic goals. As these psychodynamic concerns are being addressed, the therapist would be likely to be engaging in more direct cognitive-behavioral intervention with regard to the acute panic symptoms and tendencies toward withdrawal and somatization. Over the extended course of treatment, one might hope that Cynthia's experience with a consistent and nurturing therapist could provide the "corrective emotional experience" that should build Cynthia's self-confidence and ability to trust in intimate relationships.

\section{6-8. COURSE OF THERAPY, ONGOING MONITORING, AND CONCLUDING EVALUATION OF THE THERAPY'S PROCESS AND OUTCOME}

\section{Testing the Formulation and Treatment Plan Against the Actual Therapy}

The above formulation and treatment plan, developed by the first author of this article, is based exclusively on an analysis of Cynthia's 24 autobiographical memory narratives (see Appendix 3). The second author, applying the current coding system, had extracted these 24 memory narratives from the larger transcript of the assessment interviews and then translated them from Italian to English. The first author does not read Italian and therefore knew only the barest facts about Cynthia, with the exception of what could be gleaned from the memory narratives.

In sum, the memory coding process took place completely independently of the therapy. In this context, to explore the utility of the memory coding system for case formulation, treatment planning, and potential impact upon the actual conduct of therapy, the following challenge was undertaken. The authors generated a series of questions about the actual conduct and outcome of the therapy (see column A in Table 3). The first author then provided his best determination of the answers based on the autobiographical memory analysis (see column B in Table 3). Finally, the second author presented the same set of questions to the actual therapist in the Milan clinic who treated Cynthia. Based on her recollections and notes with regard to Cynthia's treatment, the therapist provided her own responses to the questions (see column $\mathrm{C}$ in Table 3). 


\section{Overall Agreement}

Overall, examining the author's and the therapist's pattern of responses to the questions inTable 3, we can see that the memory analysis captured some fundamental themes and disruptions in the treatment. It accurately predicted Cynthia's strong pull toward contamination of a developing therapeutic relationship. At the same time the memory analysis did not anticipate some of the extreme behavioral acting out in which Cynthia engaged. Further, the first author's predictions were predicated on a non-pharmacological treatment, but the therapist sought a pharmacological consultation and ultimately shifted the treatment to a more medicationbased intervention.

\section{Comparing the Detailed Predictions About and the Actual Therapy}

To facilitate the comparison of the predicted and actual therapeutic outcomes depicted in Table 3, we shall proceed with the analysis question-by-question, combining some questions in which there is considerable overlap.

\section{Questions 1-4: Length of Therapy, Attendance, Punctuality}

The predicted length of the therapy was 9-12 months and in actuality it lasted approximately 12 months (30 predicted sessions vs. 42 actual sessions). The prediction of a premature end to therapy after a year was based in a concern that unless the therapist worked through the client's fundamental distrust and fear of parental figures, Cynthia would begin to undermine and contaminate the therapeutic relationship. Regarding consistency of attendance, the first author suggested that Cynthia would be fairly consistent in attendance at first, but that this consistency would be jeopardized if she did not make the necessary trusting and sustained alliance with the therapist. If the initial positive transference could not overcome the underlying negative maternal transference, Cynthia was likely to engage in her various escape and withdrawal practices. In actuality, Cynthia showed a similar pattern to this anticipated one. She was very diligent and engaged with the therapy in the first two to six months, but then after some family visits and vacations, her reliability declined badly and she fell into a pattern of drinking, substance abuse, and binge-eating. She would subsequently skip sessions and not respond to phone messages.

Questions 5, 6, 7, \& 11: Therapeutic Relationship, Maternal Transference, and Retreat from Social Intimacy

The first author reasoned that at some point in the treatment Cynthia would enact her interpersonal script of imagined rejection, especially as intimacy with the therapist increased, and then follow this with social withdrawal and retreat into somatic concerns and isolation. The therapy did indeed reflect this pattern, but revealed even more borderline features of idealization, devaluation, splitting, and destructive acting out (e.g., substance abuse and promiscuity). Certainly, the object representation of Cynthia's mother that emerges from the memory analysis is in concordance with Cynthia's possible development of a borderline personality structure with regard to intimate attachments, though the extremity of acting out behaviors was not anticipated. As predicted, Cynthia's depiction of a malevolent maternal figure continued to play a significant 
role in treatment, and new revelations about the mother's negative behaviors (e.g., her excessive drinking) also surfaced.

One prediction the author could have made based on his analysis was that, because of her somatization defenses (see Question 9), Cynthia would have been responsive to medication, since this would be consistent with her view of her problems. The therapist validated this prediction in response to Question 5:

With the pharmacological therapy Cynthia decreased her use of substances: Cynthia used drugs for tranquilizers in social contexts and to treat her social phobia. Taking medicines helped Cynthia to feel that she suffered from an illness and she reduced her oppositional attitude. At this point, the therapeutic relationship became more supportive and the interventions were mainly directed to daily choices and decisions.

Although Cynthia's somatization (missing of sessions due to fatigue and illness) in response to the threat of social intimacy was predicted, the memory narratives had not provided salient evidence that substance abuse, binge-eating (there was some evidence of this on one memory), and sexual promiscuity would emerge as significant problems. However, the memory data did point to her poor ego strength, impulsivity, and self-destructive rebellious tendencies, so these behaviors can be considered more advanced manifestations of some of the petulance and negativity expressed in her childhood memories. The more traditional psychoanalytic focus of the Milan Clinic's assessment on early childhood experiences may have skewed the memories collected toward Cynthia's pre-adolescent experiences. It is possible that a more representative collection of self-defining memories, drawing on a larger sample of recent experiences (especially her adolescent years) might have counteracted the author's tendency to underestimate Cynthia's potential for these more anti-social tendencies.

\section{Questions 8 \& 12: Interpersonal Struggles and Peer Relations}

Here the predictions and Cynthia's actual behaviors were closely aligned. The memory analysis had suggested that unless Cynthia could begin to shift toward more positive self and other object representations through the mediation of the therapeutic alliance, she would continue to misfire in her efforts at building stronger peer and intimate relationships outside of treatment.

As the therapist reported, despite her initial gains in therapy, Cynthia continued to show disrupted patterns of relationships. She would start with initial idealization of peers and professors, but these positive clouds dissipated and she would focus on her "defeatist and negative self-image." She would then escape from the relational demands by plunging further into substance abuse or sexual acting out. Interestingly, some of these problematic behaviors were reduced after the consultation with the clinic psychiatrist and the application of the antianxiety medication. 


\section{Questions 9, 10,\& 14: Defenses, Emotion Regulation, and Coping Strategies}

The memories had suggested a rather intellectualized and fantasy-based defensive structure. Cynthia was unlikely to express emotion directly, and would rather hide behind somatization and isolation in response to the emergence of strong feelings. The therapy reflected this pattern, but revealed a more problematic flight into substance abuse as a way to block out feelings and avoid engagement with frightening and ego-threatening material. In a more positive vein, the author seemed to have correctly predicted that the cognitive-behavioral interventions for the panic symptoms and social anxiety would take hold, due to their more practical nature and the fact that they posed less of a dynamic threat. Cynthia's response to this prediction is described in more detail below.

Overall, along with the aid of the pharmacological intervention, Cynthia did show some improvement in her coping with her social anxiety and diminution of her acting out by the time she terminated treatment.

\section{Questions $13 \& 15$ : Success of the Therapy}

According to the author's predictions, the overall success of the therapy was contingent on the depth of alliance that might emerge between Cynthia and the therapist. If the therapy did not allow Cynthia to work through the powerful anger and fear that she had built up with regard to a negative maternal figure, then the therapy would be unlikely to shift Cynthia from the strongly embedded contamination script that she brought to the intimate relationships in her life. Although the therapist made some valuable inroads with Cynthia, it appeared that these more central dynamic concerns were not satisfactorily resolved by the end of treatment. On the other hand, there were some positive options that the author predicted and that the therapist pursued with some success. Specifically, the author suggested, in responding to Questions 13 and 14, that cognitive-behavioral strategies like "cognitive re-structuring, imagery, and relaxation could serve to help [Cynthia] with the problems of social anxiety and panic," and thus he predicted that "she may have ... learned to apply some effective self-management strategies to control her social anxiety and periods of panic." This seemed to correspeond with what happened in the therapy, as the therapist wrote in response to Questions 13 and 14 that "combining a pharmacological therapy and a more supportive psychotherapy, both psychodynamic and cognitive oriented, helped Cynthia to talk about her distrust and to return to work on the reconstruction of her interpersonal schemas," and that by the end of therapy, consistent with cognitive restructuring, "she had learned to balance her polarized representations of the world and of other people.."

\section{Conclusion}

This paper has proposed a new comprehensive coding system for analyzing and interpreting autobiographical memory narratives generated in the course of a psychotherapy evaluation. It is also applicable for extracting and coding memories from an ongoing psychotherapy. This coding system can serve three potential uses in research, psychotherapy practice, and clinical training. 
As a research tool, it provides further evidence for how individuals, like Cynthia, rely on personal memories to forge a larger sense of identity, organized around repetitive affective scripts, selective defenses, and emotion regulation strategies. Drawing on this narrative identity, one can zero in on archetypal characters, familiar plot sequences, levels of cognitive complexity and organization, and efforts at integration and meaning-making. All of these components combine to provide a variegated picture of an individual's personality dynamics.

From a clinical perspective, identification of scripts, metaphoric imagery, and potential transference patterns gives the therapist an affective and interpersonal roadmap of what is likely to transpire in the course of the therapeutic relationship. With this information compactly expressed in a small set of the client's personal memories, the therapist has access to a powerful short-hand form of communication that can keep the treatment focused on the client's most critical conflicts and enduring themes. Therapists should benefit from applying this memory system in diagnostic formulation and treatment planning. The application of the system in the case study of Cynthia provides some support for the value of narrative memory analysis in psychotherapy.

Of course the prediction exercise we employed as one approach to validating the system is quite methodologically limited. For example, the focus in the author's analysis was on historical memories, with little material about present symptoms, the contextual details of the therapy, and contextual details about what was happening in the client's life at the time of intake. However, we believe the prediction model helps to illustrate the potential of the coding system for offering effective guidance in the conduct of a particular therapy case by identifying key underlying issues in the client's personality structure and phenomenology.

As a training tool, the memory coding approach helps teach beginning clinicians how to identify critical scenes, affective sequences, recurring characters, and central metaphors that comprise the personality dynamics of their clients. Just as readers of literature must develop their skills over time to extract the most significant and thematically central passages from a text, clinicians-in-training need to practice the ability to sift through the overwhelming volume of narrative detail clients can supply in order to hone in on the material that best encapsulates a particular client's psychodynamic concerns. By using this coding system over several cases, clinicians-in-training will develop more sophisticated radar for identifying redemption and contamination sequences, turning point memories, and organizing metaphors that can become touchstones within the client-therapist communication and shared understanding of the client's critical conflicts and enduring themes.

Autobiographical narrative memories are the primary ways that individuals register and retain the meaningful moments of their past. Clients' descriptions of these memories in psychotherapy are their effort to communicate to themselves and to their therapists what has mattered and what continues to matter most in their lives. They are the building blocks of each individual's narrative identity and our ability to examine them systematically over the course of treatment should be a great asset to therapeutic understanding and intervention. 


\section{REFERENCES}

Angus, L. E., Levitt, H., \& Hardtke, K. K. (1996). Narrative process coding system: Training manual. Unpublished manuscript, York University, Toronto, Ontario, Canada.

Angus, L. E., Levitt, H., \& Hardtke, K. K. (1999). The narrative processes coding system: Research applications and implications for psychotherapy practice. Journal of Clinical Psychology, 55(10), 1255-1270.

Angus, L. E., Lewin, J., Bouffard, B., \& Rotondi-Trevisan, D. (2004). "What's the story?": Working with narrative in experiential psychotherapy. In L. E. Angus, \& J. McLeod (Eds.), The handbook of narrative and psychotherapy: Practice, theory, and research (pp. 87-101). Thousand Oaks, CA:

Angus, L. E., \& McLeod, J. (Eds.).(2004) The handbook of narrative and psychotherapy: Practice, theory, and research. Thousand Oaks, CA: Sage.

Barsalou, L. W. (1988). The content and organization of autobiographical memories. In U. Neisser \& E. Winograd (Eds.), Remembering reconsidered: Ecological and traditional approaches to the study of memory (pp. 193-243). Cambridge, MA:: Cambridge University Press.

Blagov, P. S., \& Singer, J. A. (2004) Four dimensions o self-defining memories (specificity, meaning, content, and affect) and their relationships to self-restraint, distress, and repressive defensiveness. Journal of Personality, 72, 481-511.

Bluck, S., \& Habermas, T. (2000). The life story schema. Motivation and Emotion, 24, 121-147..

Book, H. (2004). The CCRT approach to working with patient narratives in psychodynamic psychotherapy. In L.E. Angus \& J. McLeod (Eds), The handbook of narrative and psychotherapy: Practice, theory, and research. Thousand Oaks, CA: Sage.

Boritz, T., Angus, L., Monette, G., \& Hollis-Walker, L. (2008). An empirical analysis of autobiographical memory specificity subtypes in brief emotion-focused and clientcentred treatments of depression. Psychotherapy Research, 18, 584-593.

Bruhn, A. R. (1990a). Cognitive-Perceptual theory and the projective use of autobiographical memory. Journal of Personality Assessment, 55, 95-114.

Bruhn, A. R. (1990b). Earliest Childhood Memories: Theory and Application to Clinical Practice (Vol 1). New York: Praeger.

Bruhn, A. R. (1992a). The Early Memories Procedure: A projective test of autobiographical memory: I. Journal of Personality Assessment, 58(1), 1-15.

Bruhn, A. R. (1992b). The Early Memories Procedure: A projective test of autobiographical memory: II. Journal of Personality Assessment, 58(2), 326-346.

Burns, G. (2001). Healing stories: Using metaphors in therapy. New York: Wiley.

Carlson, R. (1981). Studies in script theory: I. Adult analogs of a childhood nuclear scene. Journal of Personality and Social Psychology, 40, 501-510.

Carlson, R. (1982). Studies in script theory: II. Altruistic nuclear scripts. Perceptual and Motor Skills, 55, 595-610.

Carlson, L., \& Carlson, R. (1984). Affect and psychological magnification. Derivations from Tomkins's script theory. Journal of Personality, 32, 36-45.

Charmaz, K. (2006). Constructing grounded theory: A practical guide through qualitative analysis. Thousand Oaks, CA: Sage Publications. 
Autobiographical Memory Narratives in Psychotherapy:

Conway, M. A., Singer, J. A., \& Tagini, A. (2004). The self and autobiographical memory: Correspondence and coherence. Social Cognition, 22, 491-529.

Demorest, A. P. (1995). The personal scripts as a unit of analysis for the study of personality. Journal of Personality, 63, 569-591.

Demorest, A. P. (2007). A taxonomy of scenes. Journal of Research in Personality, 42, 239246.

Demorest, A. P., \& Alexander, I. E. (1992). Affective scripts as organizers of personal experience. Journal of Personality, 60, 645-663.

Dodd, M., \& Bucci, W. (1987). The relation of cognition and affect in the orientation process. Cognition, 27, 53-71.

Gonçalves, O. F., Korman, Y., \& Angus, L. (2000) Constructing psychopathology from a cognitive narrative perspective. In R. A. Neimeyer \& J.D. Raskin (Eds.) Constructions of disorder (pp 265-284). Washington, CD: American Psychological Association.

Jobson, L., \& O'Kearney, R. (2006). Cultural differences in autobiographical memory of trauma. Clinical Psychologist, 10(3), 89-98.

Jobson, L., \& O'Kearney, R. (2008). Cultural differences in retrieval of self-defining memories. Journal of Cross Cultural Psychology, 39(1), 75-80.

Labov, W. (1997). Some further steps in narrative analysis. Journal of Narrative \& Life History, $7(1-4), 395-415$.

Labov, W. (2006). Narrative pre-construction [Special Issue: Narrative state of the art]. Narrative Inquiry, 16 (1), 37-45.

Langs, R. J. (1965a). Earliest memories and personality. Archives of General Psychiatry, 12, 379-390.

Langs, R. J. (1965b). First memories and characterlogical diagnosis. Journal of Nervous and Mental Disease, 144, 318-320.

Linton, M. (1986). Ways of searching and the contents of memory. In D.C. Rubin (Ed.) Autobiographical memory (pp.50-70). Cambridge, MA: Cambridge University Press.

Luborsky, L., \& Crits-Cristoph, P. (Eds.) (1998). Understanding transference: The core conflictual relationship theme method ( $2^{\text {nd }}$ ed.). Washington, DC: American Psychological Association.

Mayman, M. (1968). Earliest memories and character structure. Journal of Projective Techniques and Personality Assessment, 32, 303-316

McAdams, D. P. (2001). The psychology of life stories. Review of General Psychology, 5, 100122.

McAdams, D. P. (2002). Coding autobiographical episodes for themes of agency and communion. Available on the Foley Center for the Study of Lives website: (http://www.sesp.northwestern.edu/foley/).

McAdams, D. P., Hoffman, B. J., Mansfield, E. D., \& Day, R. (1996). Themes of agency and communion in significant autobiographical scenes. Journal of Personality, 64, 339-377.

McAdams, D. P., Reynolds, J., Lewis, M., Patten, A. H.,\& Bowman, P. J. (2001). When bad things turn good and good things turn bad: Sequences of redemption and contamination in life narrative and their relation to psychosocial adaptation in midlife adults and in students. Personality and Social Psychology Bulletin, 27, 474-485.

Moffitt, K. H., \& Singer, J. A. (1994). Continuity in the life story: Self-defining memories, affect, and approach/avoidance personal strivings. Journal of Personality, 62, 21-43. 
Moffitt, K. H., Singer, J. A. Nelligan, D. W., Carlson, M. A., \& Vyse, S. A. (1994). Depression and memory narrative type. Journal of Abnormal Psychology, 103, 581-583.

Pillemer, D. B. (1998). Momentous events, vivid memories. Cambridge, MA: Harvard University Press.

Pillemer, D. B. (2001). Momentous events and life story. Review of General Psychology,5, 123134.

Raffard, S., D’Argembeau, Lardi, C., Bayard, S., Boulenger, J-P., \& Van Der Linden, M. (2009). Exploring self-defining memories in schizophrenia. Memory, 17, 26-38.

Siegel, P., \& Demorest, A. (2010). Affective scripts: A systematic case study of change in psychotherapy. Psychotherapy Research, 20, 369-387.

Singer, J. A. (1997). Message in a bottle: Stories of men and addiction. New York: The Free Press.

Singer, J. A. (2001). Living in the amber cloud: A life story analysis of a heroin addict. In D. P. McAdams, \& R. Josselson (Eds.), Turns in the road: Narrative studies of lives in transition (pp. 253-277). Washington, DC: American Psychological Association

Singer, J. A. (2004a). A love story: Using self-defining memories in couples therapy. In R. Josselson, D. P. McAdams, R. Josselson, \& A. Lieblich (Eds.), Healing plots: Narrative and psychotherapy (pp. 189-208). Washington DC: American Psychological Association.

Singer, J. A. (2004b). Narrative identity and meaning-making across the adult span: An Introduction. Journal of Personality, 72, 437-459.

Singer, J. A. (2005). Personality and psychotherapy: Treating the whole person. New York: Guilford Press.

Singer, J. A. (2006). Memory, emotion, and psychotherapy: Maximizing the positive functions of self-defining memories. In R. Uttl, A. Siegenthaler, and N. Ohta (Eds.), Memory and emotion: Interdisciplinary perspectives (pp. 211-232). Oxford: Blackwell Press.

Singer, J. A., Baddeley, J. L., \& Frantsve, L. (2008). Supervision in person-centered and narrative psychotherapy. In A. K. Hess (Ed.), Psychotherapy supervision: Theory, research and practice. ( $2^{\text {nd }}$ ed., pp. 114-136). New York: Wiley.

Singer, J. A., \& Blagov, P. S. (2002). Classification system and scoring manual for self-defining autobiographical memory. Unpublished manuscript. New London: CT: Department of Psychology, Connecticut College.

Singer, J. A., \& Blagov, P. S. (2004). Self-defining memories, narrative identity and psychotherapy: A conceptual model, empirical investigation and case report. In L. E. Angus \& J. McLeod (Eds.), Handbook of narrative and psychotherapy: Practice, theory and research (pp. 229-246). Thousand Oaks, CA: Sage.

Singer, J. A. \& Bonalume, L. (2008). The Coding System for Autobiographical Memory Narratives in Psychotherapy Unpublished manuscript. New London: CT: Department of Psychology, Connecticut College.

Singer, J. A., \& Conway, M. A. (in press). Reconsidering therapeutic action: Loewald, cognitive neuroscience, and the integration of memory's duality. International Journal of Psychoanalysis.

Singer, J. A., \& Labunko-Messier, B. (in press). Using self-defining memories in couples 
treatment for older adults. In G. Kenyon, E. Bohlmeijer, \& W. Randall (Eds.) Storying later life: Issues, investigations, and interventions in narrative gerontology. New York: Oxford University Press.

Singer, J. A., \& Moffitt, K. M. (1991-92). An experimental investigation of generality and specificity in memory narratives. Imagination, Cognition, and Personality, 10, 235-258.

Singer, J. A., Rexhaj, B., \& Baddeley, J. (2007). Older, wiser, and happier? Comparing older adults' and college students' self-defining memories. Memory, 15, 886-898.

Singer, J. A., \& Salovey, P. (1993). The remembered self: Emotion, memory, and personality. New York: Free Press.

Singer, J. A., \& Salovey, P. (1996). Motivated memory: Self-defining memories, goals, and affect regulation. In L. Martin, \& A. Tesser (Eds.), Striving and feeling. New York: Erlbaum.

Singer, J. A., \& Singer, J. L. (1992). Transference in psychotherapy and daily life: Implications of current memory and social cognition research. In J.W. Barron, M.N. Eagle, \& D.L. Wolitzky, Interface of Psychoanalysis and Psychology (pp. 516-538). Washington, DC: APA Publications.

Sullivan, H. S. (1954). The psychiatric interview. New York: Norton.

Sutherland, K., \& Bryant, R. A. (2005). Self-defining memories in post-traumatic stress disorder. British Journal of Clinical Psychology, 44, 591-598.

Sutin, A. R., \& Robins, R. W. (2005). Continuity and correlates of emotions and motives in self- defining memories. Journal of Personality, 73, 793-824.

Thorne, A., McLean, K. C., \& Lawrence, A. M. (2004) When remembering is not enough: Reflecting on self-defining memories in late adolescence. Journal of Personality, 72, 513-541.

Tomkins, S. S. (1979). Script theory: Differential magnification of affects. In H.E. Howe, Jr. \& R.A. Dienstbier (Eds.), Nebraska Symposium on Motivation 1978 (Vol.26, pp. 201-236). Lincoln: University of Nebraska Press.

Tomkins, S. S. (1987). Script theory. In J. Aronoff, A.I. Rabin \& R.A. Zucker (Eds.) The emergence of personality (pp. 147-216). New York: Springer.

Weinberger, D. A. (1997). Distress and self-restraint as measures of adjustment across the life span: Confirmatory factor analyses in clinical and non-clinical samples. Psychological Assessment, 9, 132-135.

Weinberger, D. A. (1998). Defenses, personality structure, and development: Integrating psychodynamic theory into a typological approach to personality. Journal of Personality, 66, 1061-1080.

Wheeler, M. A., Stuss, D. T., \& Tulving, E. (1997). Toward a theory of episodic meory: The frontal lobes and autonoetic consciousness. Psychological Bulletin, 121, 331-354.

White, M. (2004). Folk psychology and narrative practice. In L.E. Angus \& J. McLeod (Eds.), The handbook of narrative and psychotherapy: Practice, theory, and research (pp. 1551). Thousand Oaks, CA: Sage.

White, M. \& Epston, D. (1990). Narrative means to therapeutic ends. New York: Norton.

Williams, J. M. G. (1996). Depression and the specificity of autobiographical memory. In D. C. Rubin (Ed), Remembering our past: Studies in autobiographical memory (pp. 244-267). Cambridge, MA: Cambridge University Press. 
Williams, J. M. G., Barnhofer, T., Crane, C., Hermans, D., Raes, F., Watkins, E., \& Dalgeish, T. (2007). Autobiographical memory specificity and emotional disorder. Psychological Bulletin, 133(1), 122-148.

Wood, W. J., \& Conway, M. (2006). Subjective impact, meaning making, and current and recalled emotions for self-defining memories. Journal of Personality, 74, 811-844. 


\section{$\underline{\text { Table 1. Cynthia's Four Specific Autobiographical Memories }}$}

1. [tense change - Segment 43 - mother's grandmother in Cynthia's childhood] A very important thing that I remember about my mother's grandmother is that they made me kiss her, even though I did not want to - "Kiss your grandma!" you know... and I said "Why should I? Why do I have to make such a big deal? I want to play..." ... They made me ... unwillingly. [shift- end Segment 43]

2. [Segment 62- beginning -psychologist]

Clinician: Do you remember the psychologist who saw you?

Cynthia: Yes

Clinician: And?

Cynthia: He made me play "memory." I liked it... but I didn't know... I remember that at the beginning when my mom said to me in a very sensible way... you know... she explained me that she wanted to ensure that I wouldn't have any mental problems...I broke down and cried "I'm not crazy!

Clinician: How old were you?

Cynthia: Well... 7/8 years old ... second or third school year...

Clinician: What did your mom explain to you?

Cynthia: She told me, "Well since you are sick, I'll send you to a doctor of the mind," something like that and I told her, "I'm not crazy! Leave me alone!" and I thought, 'My God, just for a thermometer!' I was scared."

Clinician: Then the situation improved because of... did you go to school again?

Cynthia: Perhaps she realized that I was faking... probably I wanted...

Clinician: You created...

Cynthia: A little bit of racket...

Clinician: Chaos...

Cynthia: I don't remember anymore what psychologist said at the end ... now I would be curious to know...

Clinician: What he said at that time? [Segment 62 - end]

3. [Segment 71 - beginning - high school choice]

Clinician: So you decided to focus on the humanities in high school. Why?

Cynthia: I don't know... but I'm angry about this choice... When I was a child I wanted to paint; I wanted to attend the art secondary school But I remember how one afternoon day, one of my cousins, 11 years older than me, and his friend (I felt in love with) ... they tried to talk me into the school focusing on humanities and I passively accepted their ideas in just a few minutes... They said, "Look at the classical school! It's better for you! You could study with us..."

Clinician: Your cousin and his friend?

Cynthia: Yes, yes, and in just a few hours they convinced me... by telling me about reasons why and friends and things to do at school... and I forgot all my own opinion and expectations and all my will and so on... I remember in the evening at dinner time I argued with my mom who disagreed because it was the same school that had rejected her after one year, but at the end, sitting over our pasta course, I was able to make her believe I was confident that this was the right choice. [Segment 71 - end] 


\section{Table 1. Cynthia’s Four Specific Autobiographical Memories (continued)}

4. [theme change - Segment 23 - event]

Cynthia: I know they have fought and they have refused to talk to each other... but they have never told me why .... An actual reason, you know... and when they reconciled three years ago, they brought it up again because some stories came to the surface ... and you know I finally understood what was happening, and what they were talking about...

Clinician: Had you heard their fights?

Cynthia: I heard my mother yelling "I was raped... and I had nothing to do with it" ... I believe that my aunt was claiming that my mom had seduced her husband...

Clinician: Do you believe that? Or did someone tell you about that?

Cynthia: I don't know... because my mom tried to defend herself from these kinds of accusations... so, anyway... the fact that nobody has ever talked to me about these stuff... it doesn't seem... so clear... why my mother has never told me about...

Clinician: Have you looked into it yourself or have you asked your sister...?

Cynthia: No, I asked her and she told me bit by bit that she had heard all these stories and she has tried to recollect everything [shift- end Segment 23]. 


\section{Table 2. Cynthia's Three Integrative Autobiographical Memories}

1. Memory 4. [tense change- Segment 5 - Motive present]

CYNTHIA: I want to enjoy my independence in Milan, but also I don't like to be with people without a sense of mutual understanding and esteem. I usually wouldn't call someone I didn't really like just to have some company. I agree with the idea "better alone than with someone who is not good company," but this idea makes me more isolated. So I don't want to call someone, but I would like to go out alone without feeling any concerns...

CLINICIAN: I know... so these concerns made you ask for help here...?

CLIENT: Yes [shift- end Segment 5]

\section{Memory 11. [tense change - Segment 31 - mother's problem]}

CYNTHIA: She has somatized a lot of things... For example she will say "Ah, today I feel a stomach ache," but thinking seriously about this, I guess they were all excuses just because of her desire to escape, to isolate herself and have a way to justify herself in front of others... just to justify her being upset... even if she said she had her period, she could justify herself ... anyway I guess... they are all ways to pass off her troubles inside...

CLINICIAN: Has she never been seen by anyone?

CYNTHIA: Oh no... my God! Not even dentists or gynecologists... you know... a psychologist? She would never see anyone who might catch the slightest hint of her craziness... [shift- end Segment 31]

\section{Memory 23. [Segment 73 - beginning - change of high school]}

CLINICIAN: And then ...

CYNTHIA : Dramatic change, I chose a high school for the arts ... Wow! Wonderful .... public school. I remember that I was miserable at the end of the first year of the classical school, because I wanted to be rejected and then I wanted to start again at the art school...

CLINICIAN: Had you chosen to transfer to the art school before the end of the year?

CYNTHIA : Yes. I had decided before I finished school... because I felt I would need a change. And then all these paintings ... [Segment 73 - end]

[Segment 74 - beginning - artistic attitude]

CLINICIAN: What did you paint usually? When did you discover your artistic tendencies?

CYNTHIA : I don't know... I remember at the nursery school that I hid the paintings that I didn't like in order to have a new white sheet, and they found all my bad paintings. I don't know... probably I liked to create something new... from white to black. I don't know - a sort of fascination... Then I was under a spell of painters...

CLINICIAN: Painters?

CYNTHIA : Yes, I felt all painters, writers and musicians were clever people... Actually I know that doing beautiful things does not mean that you are... but I created all this mythology... CLINICIAN: That it might?

CYNTHIA : Yes [Segment $74-$ end] 
Table 3: Initial Assessment-Based Predictions and Therapist's Responses at the End of Treatment, p. 1

\begin{tabular}{|c|c|c|}
\hline A. Question & $\begin{array}{l}\text { B. Predicted Responses Based on Memory } \\
\text { Analysis }\end{array}$ & C. Cynthia's Therapist's Responses \\
\hline $\begin{array}{l}01 . \text { How long did } \\
\text { the therapy last in } \\
\text { terms of months? }\end{array}$ & $\begin{array}{l}\text { I would predict that the therapy lasted roughly 9-12 } \\
\text { months }\end{array}$ & $\begin{array}{l}\text { The first assessment session was the 14th of April,2006 and the final } \\
\text { therapy session was on the } 27 \text { of September the following year } 2007 \text { when } \\
\text { Cynthia decided to leave for Spain as cultural exchange. The weekly } \\
\text { therapy began in September, } 2006 \text { and lasted } 12 \text { months. }\end{array}$ \\
\hline $\begin{array}{l}02 . \text { How many } \\
\text { sessions did } \\
\text { Cynthia attend? }\end{array}$ & $\begin{array}{l}\text { I would guess she attended roughly } 30 \text { weekly } \\
\text { therapy sessions. }\end{array}$ & $\begin{array}{l}\text { Considering also the first assessment interviews, she attended } 52 \text { sessions; } \\
\text { to be more precise, she attended } 45 \text { weekly therapeutic sessions. }\end{array}$ \\
\hline $\begin{array}{l}\text { 03. How } \\
\text { consistent was } \\
\text { Cynthia in } \\
\text { attendance? }\end{array}$ & $\begin{array}{l}\text { I would guess she was reasonably consistent with } \\
\text { occasional misses for illness or conflicting } \\
\text { commitments. }\end{array}$ & $\begin{array}{l}\text { At the beginning (first 2-6 mouths) Cynthia attended sessions regularly and } \\
\text { diligently once a week. However, in the middle of the treatment Cynthia } \\
\text { started to skip sessions repeatedly. Absences depended on two reasons: } \\
\text { *** organizational and planning: (a) Cynthia extended her Christmas, } \\
\text { Easter and summer vacations at parents house in the countryside and she } \\
\text { did not come to Milan in time; (b) when Cynthia's sister, who lived with her } \\
\text { in Milan, moved to Florence, Cynthia had trouble finding a new flat in } \\
\text { Milan: she lived with a girl friend for awhile, and then completely alone. At } \\
\text { the end of the therapy sometimes she shuttled from Brescia to Milan, and } \\
\text { vice versa because of university courses and therapy sessions. } \\
\text { *** in the middle of the therapy Cynthia's symptoms (substance abuse, } \\
\text { alcohol abuse, binging, social phobia) increased and got worse: she spent } \\
\text { whole nights drinking, smoking marijuana and abusing other drugs until } \\
\text { she became ill. She often binged and gorged, and then threw up during the } \\
\text { night. In the morning she was usually ill, tired, and weak; and she usually } \\
\text { skipped the session and turned off her phone. }\end{array}$ \\
\hline $\begin{array}{l}\text { 04. Was she } \\
\text { punctual in } \\
\text { attendance? }\end{array}$ & $\begin{array}{l}\text { I think she might have had a tendency to come a little } \\
\text { bit late. }\end{array}$ & When she decided to come to session, she was absolutely punctual. \\
\hline
\end{tabular}




\section{Table 3: Initial Assessment-Based Predictions and Therapist's Responses at the End of Treatment, p. 2}

\begin{tabular}{|c|c|c|}
\hline A. Question & $\begin{array}{l}\text { B. Predicted Responses Based on Memory } \\
\text { Analysis }\end{array}$ & C. Cynthia's Therapist's Responses \\
\hline $\begin{array}{l}05 . \text { What was the } \\
\text { quality of your } \\
\text { relationship with } \\
\text { Cynthia? }\end{array}$ & $\begin{array}{l}\text { There could be two directions that Cynthia would take } \\
\text { the relationship. } \\
\text { *** She either would use the therapy to find a } \\
\text { positive maternal figure and if so, after early } \\
\text { resistance, would truly bond and connect in a } \\
\text { corrective and nurturing way with the therapist, or } \\
\text { *** She would be too defended to form a deep } \\
\text { alliance with the therapist and instead would remain } \\
\text { rather vague, abstract, and somewhat aloof from the } \\
\text { treatment. If she could not let go to develop a deep } \\
\text { positive transference, then she would would have been } \\
\text { likely to shut down, withdraw, employ irony and } \\
\text { cynicism. This would be a repetition of the } \\
\text { contamination sequences that are highly prominent in } \\
\text { her memory narratives. }\end{array}$ & $\begin{array}{l}\text { The quality of relationship with Cynthia changed during treatment. We } \\
\text { can describe three steps. } \\
\text { *** At the beginning she seemed in alliance and happy with the therapy; } \\
\text { her lack of important caring relationships and her deep loneliness } \\
\text { emerged. In this phase the therapist was an important emotional support. } \\
\text { At the beginning I was really confident about her well-being and possible } \\
\text { improvement; I believed she would be able to face all relational and } \\
\text { emotional conflicts that had emerged in the assessment sessions. } \\
\text { *** However, at the } 6^{\text {th }} \text { mouth I realized that the therapeutic alliance was } \\
\text { just apparent and not genuine. Cynthia's mood and symptoms started } \\
\text { worsening, including alcohol, drugs, and eating disorders (binging and } \\
\text { intoxication). She became discouraged and resigned, and defeatist; and } \\
\text { sometimes oppositional. She usually used passive-aggressive defenses to } \\
\text { face the situation (skipping sessions, keeping her cell phone off). } \\
\text { *** At this point, I decided to work on this mistrust by asking for a } \\
\text { pharmacological consultation. She began to take anxiolytic and } \\
\text { antidepressant drugs. With the pharmacological therapy Cynthia } \\
\text { decreased her use of substances: Cynthia used drugs for tranquilizers in } \\
\text { social contexts and to treat her social phobia. Taking medicines helped } \\
\text { Cynthia to feel that she suffered from an illness and she reduced her } \\
\text { oppositional attitude. At this point, the therapeutic relationship became } \\
\text { more supportive and the interventions were mainly directed to daily } \\
\text { choices and decisions. }\end{array}$ \\
\hline
\end{tabular}


A Coding System Applied to the Case of Cynthia

J.A. Singer \& L. Bonalume

Pragmatic Case Studies in Psychotherapy, http://pcsp.libraries.rutgers.edu

Volume 6, Module 3, Article 1, pp. 134-188, 11-09-10 [copyright by authors]

\section{Table 3: Initial Assessment-Based Predictions and Therapist's Responses at the End of Treatment, p. 3}

\begin{tabular}{|c|c|c|}
\hline A. Question & B. Predicted Responses Based on Memory Analysis & C. Cynthia's Therapist's Responses \\
\hline $\begin{array}{l}\text { 06. Did you } \\
\text { notice any } \\
\text { transference } \\
\text { dynamics? }\end{array}$ & $\begin{array}{l}\text { I allude to transference dynamics in the previous response } \\
\text { but to recapitulate - her transference depends on her } \\
\text { willingness to engage in treatment. If she remained } \\
\text { treatment resistant, then she was likely to have retained a } \\
\text { negative and distrustful transference, turning the therapist } \\
\text { into a threatening and inconsistent mother figure. If she } \\
\text { engaged in treatment, she was more likely to develop slowly } \\
\text { a warm and more vulnerable stance toward the therapist, } \\
\text { granting her the position of a surrogate positive maternal } \\
\text { figure. } \\
\text { Not knowing the demeanor of the therapist, it is difficult to } \\
\text { predict which of these scenarios is more likely. I can say } \\
\text { that if the personality of the therapist leans toward a softer } \\
\text { and humanistic style, it is more likely the positive } \\
\text { transference developed. If the therapist's personality is } \\
\text { more didactic and formal, I would imagine that Cynthia } \\
\text { would have balked at deepening her relationship to her } \\
\text { therapist }\end{array}$ & $\begin{array}{l}\text { I was particularly influenced by a sense of distrust from Cynthia and } \\
\text { I was afraid of losing her. My choice to consult a colleague- } \\
\text { psychiatrist helped to dissolve this transference dynamic. }\end{array}$ \\
\hline $\begin{array}{l}07 . \text { Did you } \\
\text { notice a pattern of } \\
\text { Cynthia retreating } \\
\text { from social } \\
\text { intimacy, either } \\
\text { with you or with } \\
\text { others outside the } \\
\text { therapy? }\end{array}$ & $\begin{array}{l}\text { Cynthia continued to show difficulties in making new friends } \\
\text { and displayed periods of isolating herself. There would be } \\
\text { periods of intellectualization and remoteness in the } \\
\text { therapeutic relationship. Tentative efforts toward alliance } \\
\text { and trust might alternate with periods of guarded } \\
\text { withdrawal and even possible denigration of the need for } \\
\text { treatment. If the alliance built showed sufficient strength, } \\
\text { these fluctuations would begin to dissipate and she would } \\
\text { form a more dependent, trusting, and nurturing relationship } \\
\text { to the therapist. }\end{array}$ & $\begin{array}{l}\text { To me, Cynthia's interpersonal and relational functioning have } \\
\text { always been characterized by an oscillation between withdrawal } \\
\text { and fantastic escapism from reality, as well as a tendency to resist } \\
\text { and reject social and common rules, leading to sociopathic } \\
\text { behaviors (promiscuity, dangerous friendships, risk of life). } \\
\text { Whenever our relationship became closer and the therapy affected } \\
\text { her self-representation and her representations of others, Cynthia } \\
\text { withdrew and retreated from the social intimacy by using substances } \\
\text { and drugs. During therapy her social withdrawal decreased slowly } \\
\text { because she relied on the medication to overcome her social phobia. }\end{array}$ \\
\hline
\end{tabular}


A Coding System Applied to the Case of Cynthia

J.A. Singer \& L. Bonalume

Pragmatic Case Studies in Psychotherapy, http://pcsp.libraries.rutgers.edu

Volume 6, Module 3, Article 1, pp. 134-188, 11-09-10 [copyright by authors]

\section{Table 3: Initial Assessment-Based Predictions and Therapist's Responses at the End of Treatment, p. 4}

\begin{tabular}{|c|c|c|}
\hline A. Question & $\begin{array}{l}\text { B. Predicted Responses Based on Memory } \\
\text { Analysis }\end{array}$ & C. Cynthia's Therapist's Responses \\
\hline $\begin{array}{l}08 . \text { Did you } \\
\text { notice any } \\
\text { repetitive } \\
\text { interpersonal } \\
\text { struggles or } \\
\text { dilemmas that } \\
\text { were distressing or } \\
\text { self-defeating for } \\
\text { Cynthia? }\end{array}$ & $\begin{array}{l}\text { She continued to have negative interactions with } \\
\text { her mother and increasingly tried to distance } \\
\text { herself from her. She was very tentative and } \\
\text { ambivalent in her efforts to make new friends. } \\
\text { If she made tentative forays into new } \\
\text { relationships, and they met with mixed results, } \\
\text { she would be likely to retreat with a mixture of } \\
\text { hurt and pride. }\end{array}$ & $\begin{array}{l}\text { Cynthia's personal and interpersonal conflicts were often linked to the contrast } \\
\text { between the tendency to idealize other people and a defeatist and negative self- } \\
\text { image. For a long time, for example, I worked to help Cynthia submit an essay to } \\
\text { her art professor because she always considered her works inadequate. The } \\
\text { same conflict was clear in her relationships with boyfriends: Cynthia tended first } \\
\text { to idealize boys she met, and then finally felt inadequate with them. During the } \\
\text { most difficult step of the therapy, in a state of altered consciousness through } \\
\text { alcohol and drugs, Cynthia would usually have sex with anyone. }\end{array}$ \\
\hline $\begin{array}{l}\text { 09. What were her } \\
\text { most prominent } \\
\text { defenses? }\end{array}$ & $\begin{array}{l}\text { Her most prominent defenses were a certain } \\
\text { intellectualized abstractness; some retreat into } \\
\text { fantasy; a tendency toward isolation. There is } \\
\text { some possible somatizaton. }\end{array}$ & $\begin{array}{l}\text { Denial; passive-aggression; devaluation, idealization; splitting self and other } \\
\text { images; and isolation }\end{array}$ \\
\hline $\begin{array}{l}\text { 10. What were the } \\
\text { most prominent } \\
\text { strategies did she } \\
\text { use to control her } \\
\text { emotions? }\end{array}$ & $\begin{array}{l}\text { I would guess intellectualization, reaction } \\
\text { formation, somatization, and isolation. }\end{array}$ & $\begin{array}{l}\text { Withdrawal, compulsive abuse of substances, magic thought and fantastic } \\
\text { escapism }\end{array}$ \\
\hline $\begin{array}{l}\text { 11. Was her } \\
\text { mother a dominant } \\
\text { figure in her } \\
\text { conversations with } \\
\text { you? }\end{array}$ & $\begin{array}{l}\text { She did continue to return to her mother as a } \\
\text { negative and malevolent figure in her life. }\end{array}$ & $\begin{array}{l}\text { Not dominant, but really important. The mother was surely a negative character } \\
\text { in Cynthia's life story and Cynthia was the child who suffered more than others } \\
\text { from her mother's influence. During therapy, Cynthia remembered more about } \\
\text { her mother in her childhood: she usually drank and she was often intoxicated. } \\
\text { She was unable to take care of her children, apart from cooking for them and } \\
\text { clothing them. Cynthia told me that when she had had a serious eating disorder } \\
\text { and she had been very thin, her mother tried to comfort her by saying: "Would } \\
\text { you like new bigger tits?" }\end{array}$ \\
\hline
\end{tabular}


A Coding System Applied to the Case of Cynthia

J.A. Singer \& L. Bonalume

Pragmatic Case Studies in Psychotherapy, http://pcsp.libraries.rutgers.edu

Volume 6, Module 3, Article 1, pp. 134-188, 11-09-10 [copyright by authors]

Table 3: Initial Assessment-Based Predictions and Therapist's Responses at the End of Treatment, p. 5

\begin{tabular}{|c|c|c|}
\hline A. Question & B. Predicted Responses Based on Memory Analysis & C. Cynthia's Therapist's Responses \\
\hline $\begin{array}{l}\text { 12. Did she } \\
\text { continue to have } \\
\text { trouble with her } \\
\text { peer relationships? }\end{array}$ & Yes, these continued to be problematic. & $\begin{array}{l}\text { Yes, her substance abuse first and later her medications helped her to } \\
\text { overcome her social anxiety. }\end{array}$ \\
\hline $\begin{array}{l}\text { 13. What } \\
\text { therapeutic } \\
\text { interventions were } \\
\text { the most } \\
\text { successful in the } \\
\text { treatment? }\end{array}$ & $\begin{array}{l}\text { I would imagine that the provision of a positive } \\
\text { maternal transference would serve a corrective function } \\
\text { in her life. More concretely, I would think that self- } \\
\text { management strategies of cognitive re-structuring, } \\
\text { imagery, and relaxation could serve to help with the } \\
\text { problems of social anxiety and panic. }\end{array}$ & $\begin{array}{l}\text { First of all using data from the assessment process (bio-psycho-social } \\
\text { data and data from personality test) had revealed her mistrust and } \\
\text { distrust. Then, my choice to re-think the treatment strategy, by } \\
\text { combining a pharmacological therapy and a more supportive } \\
\text { psychotherapy, both psychodynamic and cognitive oriented, helped } \\
\text { Cynthia to talk about her distrust and to return to work on the } \\
\text { reconstruction of her interpersonal schemas. }\end{array}$ \\
\hline $\begin{array}{l}\text { 14. Did Cynthia } \\
\text { learn to apply } \\
\text { more constructive } \\
\text { coping strategies? }\end{array}$ & $\begin{array}{l}\text { If the alliance ended up successful, I would suggest that } \\
\text { Cynthia learned to be more giving and receptive in her } \\
\text { relationships. She may have also learned to apply some } \\
\text { effective self-management strategies to control her } \\
\text { social anxiety and periods of panic. If not, she would } \\
\text { continue to rely on isolation, withdrawal, fantasy, and } \\
\text { other avoidant strategies. }\end{array}$ & $\begin{array}{l}\text { Even though the therapy stopped prematurely, because of her choice to } \\
\text { move to Spain for a cultural exchange, she had learned to balance her } \\
\text { polarized representations of the world and of the other people. She } \\
\text { seemed able to contact people in a more balanced way. She became a } \\
\text { little bit more aware of the risks in her life. }\end{array}$ \\
\hline $\begin{array}{l}15 . \text { Overall, } \\
\text { would you } \\
\text { consider the } \\
\text { therapy } \\
\text { successful? }\end{array}$ & $\begin{array}{l}\text { My prediction is if the initial alliance took hold, then the } \\
\text { therapy should have been able to improve her } \\
\text { relationship efforts and reduce her social anxiety. If the } \\
\text { alliance did not form strongly, then I would imagine that } \\
\text { the therapy was more patchwork with intermittent } \\
\text { progress and eventual decline in attendance and } \\
\text { commitment on behalf of the client. }\end{array}$ & $\begin{array}{l}\text { Cynthia still needed treatment at the end of the therapy process; } \\
\text { however she was more able to take care of herself than in the past; she } \\
\text { was acting out less and much more in contact with reality. }\end{array}$ \\
\hline
\end{tabular}


Figure 1. The Coding System for Autobiographical Memory Narratives in Psychotherapy (CS-AMNP; Singer \& Bonalume, 2008)

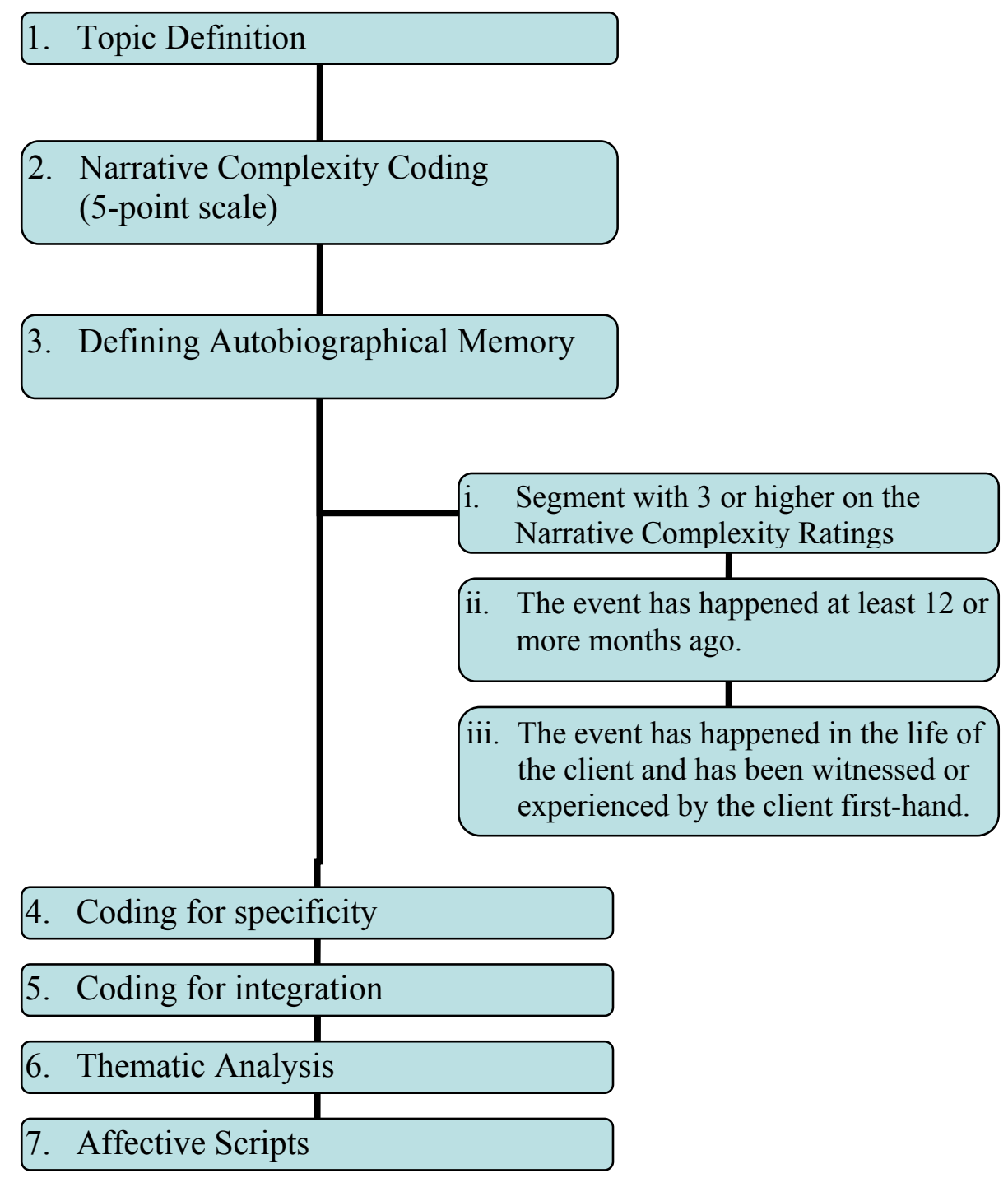


Figure 2. Distribution of Cynthia's topic segments according to a 5-point- scale for "narrative complexity" $(\mathrm{N}=75)$

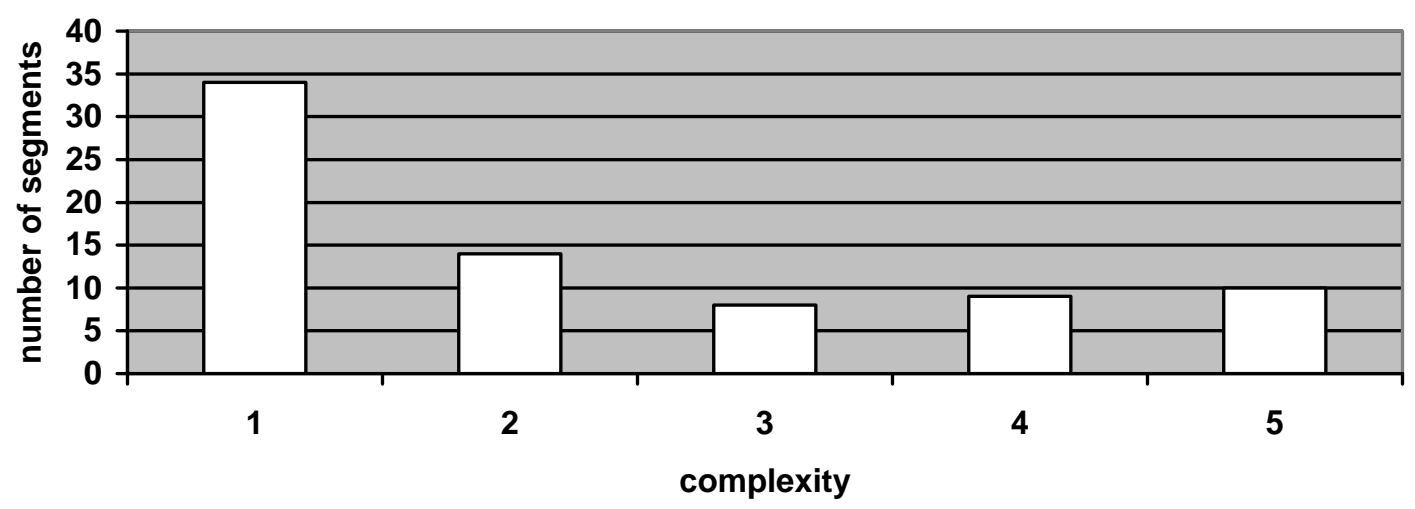

Figure 3. Coding for Specificity for Cynthia's Autobiographical Memories. ( $\mathrm{N}=24)$

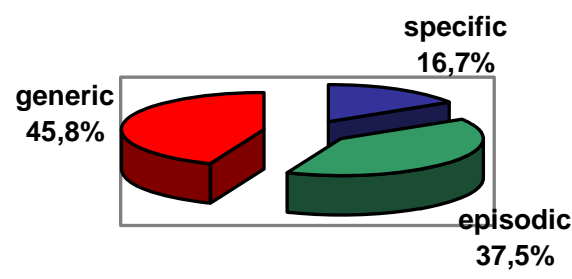

Figure 4. Coding for Integration for Cynthia's Autobiographical Memories. $(\mathrm{N}=24)$

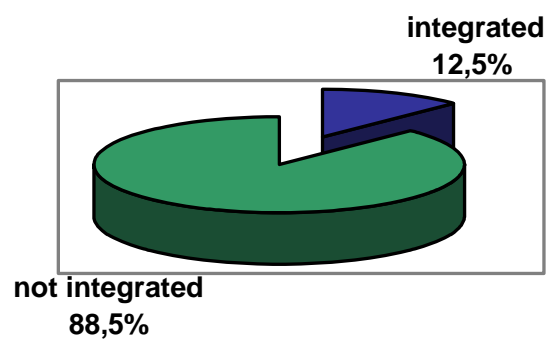




\section{APPENDIX 1. SELECTED CLINICAL EXAMPLES FROM PREVIOUS STUDIES OF MEMORY ANALYSIS IN PSYCHOTHERAPY}

1. (Singer \& J. L. Singer, 1992) - Individual case study in which a highly intelligent client who suffers themes of shame and low esteem recalls a kindergarten memory in which he breaks a pencil and the teacher shames him in front of the entire class and then banishes him to a coat closet. Despite a college education and M.A. degree, the client isolates himself from others and works as a house cleaner. The therapist makes use of the broken pencil memory as a metaphor and affective script in his relationships and transference dynamics.

2. (Singer, 1997) - Individual case study of a gay man suffering from drug addiction and AIDS who describes a memory of how he found his greatest sense of validation during his prison years when he was sought after as a desirable sexual object - "the jewel of prison." This memory image was used to capture how his pleasure and sense of value often contained a self-destructive dimension.

3. Singer (2001) - Individual case study of a heroin addict and hustler who recalled a memory of how when, as a child, he learned that he would get money from the tooth fairy, he purposely pulled his front teeth out. The permanent teeth subsequently came in twisted and overlapping. This memory became a metaphor in his relationships and transference dynamics for how he was willing to manipulate and compromise himself for money and self-gain, even at the expense of his self-respect.

4. Singer (2004) - Case study of couple in which dying husband seeks reconciliation with his wife and they both recall the same memory from 17 years earlier in which the husband returning from an alcohol rehabilitation is unable to accept his wife's out-stretched hand and from that moment forward they ceased to have any physical intimacy with each other. In the course of the therapy, the therapist was able to enlist the couple to engage in a reverse role play of this memory as a way to energize compassion and forgiveness with each other.

5. Singer (2006) - Case study of couple in which wife is frustrated with husband's perceived passivity and lack of care-taking. She recalls over-idealized memories of her father's heroic examples of nurturing and competence as a way to express her dissatisfaction with her husband. The therapist helps the wife look at these memories in a more realistic light and reframe them as the husband makes more conscious efforts to be more proactive and helpful in the relationship. 


\section{APPENDIX 2. THE CODING SYSTEM}

\section{$\underline{\text { Step 1. Topic Definition (see Figure 1) }}$}

The first step in this process divides the interview transcripts into defined segments, identifiable through topic changes, new lines of inquiries by the questioner, and noticeable shifts in verb tenses that signal a changing in focus from the current topic. A segment contains a specific "topic," such as an event description, a relationship, a reflection on a person, a feeling or a state of being (Dodd \& Bucci, 1987) to which we one can assign a "title." The beginning of a new topic segment is identified when a shift or change in subject occurs (Angus, Levitt, \& Hardtke, 1996, 1999), either due to an external stimulus, such as questions posed by the therapist ("Tell me about another incident from your childhood?"), or clear signs of transition to a new topic ("so, now we could talk about your mother's family"), or by an internal stimulus, such as when the client clearly introduces a new topic ("I've got to tell you what happened") (Labov, 2006) or even a direct introductory statement ("Anyway, I remember another incident..." or "The next big event in my life was..."). The ending of a topic segment is often marked by either an affirmation that what has been said has been understood by the therapist and/or the client or a relevant long pause in the conversation (ex. "Mm hmm") or a summary of the preceding issues.

\section{Step 2. Narrative Complexity Coding (see Figure 1)}

Once the transcript is divided into discrete topic segments, the next step in this process is to differentiate narrative segments from non-narrative segments within each topic segment. In making this narrative/non-narrative distinction, we relied on the work of Labov (1997) and Gonçalves, Korman and Angus (2000) who have highlighted the concept of narrative complexity with regard to causality, temporality, and outcome, as well as representations of protagonists and antagonists, along with emotional responses. Each segment was coded for Narrative Complexity, using a 5-point scale, applying the following criteria in italics below. An example from Cynthia's material is provided for each criterion.

$\rightarrow 5$ pt. narrative. A narrative episode with causal linkages and temporal sequencing among the events, and a clear outcome that arises from the events. General descriptions of emotions and representations of people along with other details are likely to be present.

For example, in the following segment Cynthia describes a specific event with a beginning (mother's and aunt's relationship before the event), action sequence (client hears a fight between her mother and aunt), and causal consequences (client relates how the fight affected the two women), along with an explanation for the events (client explains the motive behind the fight); all components are linked together not only by a causal relation, but also by a temporal juncture; a time marker is identified ("three years ago"); the client also describes feelings and thoughts of all the characters.

[theme change - Segment 23 - event]

Cynthia: I know they have fought and they have refused to talk to each other... but they have never told me why .... An actual reason, you know... and when they reconciled three years ago, 
they brought it up again because some stories came to the surface ... and you know I finally understood what was happening, and what they were talking about...

Clinician: Had you heard their fights?

Cynthia: I heard my mother yelling "I was raped... and I had nothing to do with it" ... I believe that my aunt was claiming that my mom had seduced her husband...

Clinician: Do you believe that? Or did someone tell you about that?

Cynthia: I don't know... because my mom tried to defend herself from these kinds of accusations... so, anyway... the fact that nobody has ever talked to me about this stuff... it doesn't seem... so clear... why my mother has never told me about...

Clinician: Have you looked into it yourself or have you asked your sister...?

Cynthia: No, I asked her what she knew and slowly she told me that she had heard these stories and tried to put the pieces of what she had heard together. [shift - end Segment 23]

$\rightarrow 4$ points. A narrative episode with causal linkages among the events and temporal sequencing, but a confused or absent outcome. General descriptions of emotions, feelings, representations of people's details may be present, as in the following segment:

[theme change - Segment 17 - event past]

Cynthia: This is an incident that my father tells...

Clinician: About your mother's father?

Cynthia: Yes

Clinician: So your dad tells something about his father-in-law...

Cynthia: First, my grandfather was against my father who isn't noble and so he sounded strict and intransigent ... and at the end when my father won over my mother, my grandfather said to him "Well, you know that she is crazy." I don't know, but it sounds very strange that a father would say this to his future son-in-law...It's a strong judgment....

Clinician: And what did your father think?

Cynthia: I don't know. I think he tried to be more conventional... to be a little bit more levelheaded...

Clinician: So have your parents never had difficulties in their relationship with your grandparents? [shift - end Segment 17]

$\rightarrow 3$ points. A narrative episode with at least causal linkages among the events, but without clear temporal sequencing or outcome of the events. General descriptions of emotions, 
feelings and, representations of people's details may be present. No time markers are identified.

Even if the following sequence is confused and generalized, Cynthia describes a brief episode with causal linkage between her mother's physical status and her behavior; no time makers are identified.

[tense change - Segment 31 - mother's problem]

Cynthia: She has somatized a lot of things... For example she will say "Ah, today I feel a stomach ache," but thinking seriously about this, I guess they were all excuses just because of her desire to escape, to isolate herself and have a way to justify herself in front of others... just to justify her being upset... even if she said she had her period, she could justify herself ... anyway I guess... they are all ways to pass off her troubles inside...

Clinician: Has she never been seen by anyone?

Cynthia: Oh no... my God! Not even dentists or gynecologists... you know... a psychologist? She would never see anyone who might catch the slightest hint of her craziness... [shift - end Segment 31]

$\rightarrow 2$ points. A general description of emotions, feelings, representations of people details with some general examples about actions or places where the episode has taken place without any causal linkage, temporal juncture or endpoint of actions. ("We had very few toys when we were children"; "we used our imagination..."; "we did not have much money and hid from the bill collectors...”).

For example, in addition to the descriptions of her mother's general attitude and feelings when she was a child, Cynthia adds some examples, as actions or general events, but without any temporal or causal links.

[theme change - Segment 28 - mother during client's childhood]

Clinician: What did she do when you were a child?

Cynthia: It was a big house... she didn't tolerate servants; she didn't want foreigners in her home... so she had a big house which occupied her a lot, and she took care of the children too... now she has nothing to do and she usually watches TV or she looks after the yard. Now she doesn't tell stories about children anymore, but she talks about her dogs...

$\rightarrow 1$ point. A general description of emotions, feelings, representations of people, or other details without any causal or temporal sequence ("My father was an angry man...; "We were happy”).

In the following segment, Cynthia comments on what her mother was like when she was a child and judges her in a negative way. 
[theme change - Segment 29 - judgment of the mother]

Cynthia: Yes ... I don't know... because these things don't sound so bad, but she is what I would never want to become... She is a failed woman in the sense that she is 55 years old and without her children to take care of and she has nothing to do ... But if I think of her as my mother ... she was sensible ... I don't have any other positive adjectives for her ... Now I see her in an overly negative way ... it's hard to swallow my disillusionment ... [shift- end Segment 29]

\section{Step 3. Defining the Autobiographical Memory (see Figure 1)}

Once the segment is coded as a viable narrative (a 3 or higher on the Narrative Complexity Ratings), then in order to be coded as an autobiographical memory, it must meet the following criteria:

It is an event that happened at least 12 or more months ago.

According to some authors, a memory becomes autobiographical after two years from the event happening (Linton, 1986). In the coding system, drawing on work with self-defining memories, the period of one year was judged to be sufficient time to allow the long-term memory to "set." Events from within the last 12 months are coded as "Not Past."

The event has happened in the life of the client and has been witnessed or experienced by the client first-hand. It cannot be a story heard from another person or the description of a book, film, or play.

So when Cynthia told a story about her mother, "She went to the classical high school for one year and they were going to reject her," this is not acceptable. In contrast, when Cynthia describes how she would listen to her grandmother's stories - "... She made me long for and dream about, those tales of carriages and noble parties," it is acceptable because she is recounting her personal experience of listening to her grandmother tell her stories.

Past narrative episodes that contain this direct personal experience are called Autobiographical; past narrative episodes that do not contain this personal experience are called Non-autobiographical.

\section{Step 4. Coding for Specificity}

Having now defined the criteria to identify an autobiographical memory narrative, the memory can be assessed for its structural specificity, using the Classification System and Scoring Manual for Self-defining Memories (Singer \& Blagov, 2002). According to Singer and Blagov (2002), memory specificity captures the degree to which a particular memory makes reference to a unique occurrence located in a particular moment in time, traceable to a specific location. A specific autobiographical narrative is a single unit that contains events within a one-time defined instance occurring in no more than a day or a night and the following morning. In contrast, nonspecific memory narratives usually span more than a day and often much longer or are composed 
of equivalent events that are repeated over time intervals or fused together, blending the same characters, settings, happenings, and emotions.

These different forms of memory structure yield the following categories (Blagov \& Singer, 2004; Singer \& Moffitt, 1991-92; Singer \& Salovey, 1993): single event memories that are traceable to a specific defined moment in time within one 24-hour period (e.g., "My mother called me at school to tell me that she opened my acceptance letter to college. We both burst into tears of relief and joy."), summary episodic memories that collect together a number of closely-occurring single events into one compacted time period (e.g., "During the vacation, we swam, snorkeled, sunned, and went dancing at night"), and summary generic memories that blend the repeated occurrences of a similar event separated over larger blocks of time into an amalgamated single recollection (e.g., "Growing up, I went to the park with my father every Sunday"). Other researchers (Barsalou, 1988; Boritz et al., 2008; Williams, 1996; Williams, Barnhofer, Crane, Hermans, Raes, Watkins, \& Dalgeish, 2007) have made similar distinctions in characterizing memory retrieval and narrative structure. Regarding specificity in self-defining memories, studies have determined that specificity is inversely related to defensiveness (Blagov \& Singer, 2004; Singer \& Salovey, 1993) and greater specificity of positive memories is related to mood regulation in non-depressed individuals (Moffitt, Singer, Nelligan, Carlson, \& Vyse, 1994).

Here are examples for each category of memory structure from Cynthia's protocol:

"I hear my mother yelling [at my aunt], 'I was raped...I had nothing to do with it.' I believe that my aunt was accusing my mother of seducing her husband." (specific memory)

"The real crisis and traumatic moment came five years ago...My parents had a severe rift...frequent fights; they talked about divorce. My father rented a flat..." (summary episodic memory)

"When I was at middle school in this small town, the other children called me "little countess." (summary generic memory)

As long as a memory narrative contains a defined specific episode with sufficient detail and imagery within a 24-hour period, the memory is coded as specific, even if it is embedded in a larger episodic or generic memory.

\section{Step 5. Coding for Integration (see Figure 1)}

In addition to determining an autobiographical memory narrative's specificity, one can also code the memory for its degree of integration with the larger self-concept of the individual (Pillemer,1998, 2001; Thorne, McLean, \& Lawrence, 2004), Although it is possible to make interpretive inferences about the meaningfulness or degree of self-integration contained within a particular memory narrative, Singer and Blagov (2002) developed a reliable and valid scoring method for coding memory integration based on explicit integrative statements contained within the memory narrative (e.g. "This memory taught me that....," "Ever since this memory, I have understood that ...," "The lesson I took away from this memory is..."). Blagov and Singer 
(2004) demonstrated that individuals with larger numbers of these meaning statements in their self-defining memories showed greater self-restraint and optimal adjustment as measured by the Weinberger Adjustment Inventory - Short Form (WAI-SF; Weinberger, 1997, 1998).

The scoring system discriminates between integrative and non-integrative narrative memories. The integrative narratives involve stepping back from the memory and extracting a lesson that transcends the remembered events. In the following example from Cynthia's protocol, we have italicized the phrases in the memory that qualify it as an integrative memory.

Cynthia: She has somatized a lot of things... For example she will say "Ah, today I feel a stomach ache," but thinking seriously about this, I guess they were all excuses just because of her desire to escape, to isolate herself and have a way to justify herself in front of others... just to justify her being upset... even if she said she had her period, she could justify herself ... anyway I guess... they are all ways to pass off her troubles inside...

Clinician: Has she never been seen by anyone?

Cynthia: Oh no... my God! Not even dentists or gynecologists... you know... a psychologist? She would never see anyone who might catch the slightest hint of her craziness... [shift- end Segment 31]

Step 6. Thematic Analysis (see Figure 1)

In the next two steps we turn to consideration of key life themes, as well as more general affective patterns, object representations, defenses, and self-regulation strategies (Demorest, 2007; McAdams, 2002; Tomkins, 1979). To assist the thematic analysis of autobiographical memory narratives, one can utilize the scoring criteria from Dan McAdams's Foley Center website, (http://www.sesp.northwestern.edu/foley/instruments/).

This site offers a reliable method for coding memory narratives for Agency (themes of power, achievement, mastery, independence, autonomy, separation) and Communion (themes of relationship, connection, intimacy, nurturance, helping, togetherness). It also provides guidelines for how to code memory narratives for redemption and contamination sequences. Redemption sequences begin with negative events that center on struggles, obstacles, and setbacks, but end with moments of triumph, growth, rejuvenation, and positive emotion. Contamination sequences begin with hope or positive circumstances and end in frustration, disappointment, and dejection.

With respect to agency and communion, McAdams has found that these themes in memories correlate with overall motivational tendencies and individuals' long-term goals that reflect the respective balance of these two dimensions in their personalities (McAdams, Hoffman, Mansfield, \& Day, 1996). Regarding redemption/contamination sequences, individuals with higher numbers of redemption sequences in a set of narrative memories tend to show higher levels of self-esteem, well-being, and life satisfaction, while individuals with more contamination sequences are more prone to depression, lower self-esteem, and more discontent with their lives (McAdams, Reynolds, Lewis, Patten, \& Bowman, 2001). Relevant examples from McAdams' work are provided below. 


\section{- Agentic Memory Narrative Example:}

Every Saturday home game the marching band performs a highly demanding thirteen minute show that requires us to push ourselves to our limits. I loved the performance exhilaration and constantly challenging myself to perform better than before - to push my limits and grow as an individual. (http://www.sesp.northwestern.edu/foley/instruments/agency/, retrieved June 30th, 2009)

- Communal Memory Narrative Example

My mother and I talked in depth about the problems my brother was having. I felt like so much of who I have become is like my mother. I felt warmth and closeness when we said good-bye. (http://www.sesp.northwestern.edu/foley/instruments/communion/ retrieved June 30th, 2009)

\section{- Redemption Sequence}

Example 1: difficult years working in a low-paying job ---> money saved enhanced child's education

Example 2: depression ---> regained positive outlook on life (http://www.sesp.northwestern.edu/foley/instruments/redemption/ retrieved June 30th, 2009)

\section{- Contamination Sequence}

Example 1: Leading the pack in a race --> collapses, finishes last

Example 2: Pride at graduation --> shame at father's criticism of her weight (http://www.sesp.northwestern.edu/foley/instruments/contamination/ retrieved June 30th, 2009)

\section{Step 7. Affective Scripts (see Figure 1)}

Redemption and Contamination sequences can be considered a subset of the larger construct of Affective Scripts, first defined by Tomkins $(1979,1987)$ and examined empirically by Carlson (1981, 1982; Carlson \& Carlson, 1984) and Demorest (Demorest (1995, 2007; Demorest \& Alexander, 1992; Siegel \& Demorest, 2010). Tomkins argued that individuals organize and respond to experiences in their lives by finding similarities in their affective responses across events. The repetition of these similar affective experiences coalesces in a more abstracted template or "script" that allows us to anticipate new events and respond to them through the filter of this script. Over time we not only accumulate new experiences that match familiar ones, but our scripts begin to shape these new experiences to fit with our existing template. In the aforementioned case studies (Singer, 2001, 2004; Singer et al., 2008; Singer \& Salovey, 1993; Singer \& Singer, 1992), Singer demonstrated how not only these affective scripts, but repetitive object representations, defenses, and self-regulation strategies can be identified across a set of autobiographical memory narratives. For example, in the Singer et al. (2008) case study described at the beginning of this paper, the client's self-defining memories shared a common theme of humiliation by authority figures. These memories also contained 
negative body image self-representations and sequences of events that centered on unacknowledged accomplishments.

Although there is no established coding system for extracting affective scripts from a set of narrative memories (however, see the recent work on extracting scripts from any form of narrative recently published by Siegel \& Demorest, 2010), we use a grounded theory approach (Charmaz, 2006) in that we begin with the raw memory narratives and attempt to identify any affective sequences that are repeated across the set of narratives. Once a particular affective script seems to emerge, we look to see if this script fits with and informs the other biographical and personality data that have been collected in the biopsychosocial interview. Does the script offer a helpful theoretical framework for making sense of the individual's attitudes, behaviors, and interpersonal interactions? A successful script analysis will often yield an overarching metaphor that captures a central concern or conflict for the client. 


\section{APPENDIX 3: THE 24 AUTOBIOGRAPHICAL MEMORY NARRATIVES, p. 1}

1. [Segment 2 - beginning- parent's relationship]

CLINICIAN: What about your parents' relationship when you were a child?

CYNTHIA: Well... I guess...

CLINICIAN: You have already told me about huge fights...

CYNTHIA: Yes... anyway... I was a little bit older... fifth year at the elementary school.... Something also at the nursery school... as soon as you are a child they tried to manage these stuff by themselves... the fights, discussions... and then I guess their marriage had up till then... They tried to keep their marriage alive... home, a child, another one... and so on... CLINICIAN: And then...

CYNTHIA: It had been affected...

CLINICIAN: When?

CYNTHIA: To me... I remember just that my siblings had already understood more than me while I was just able to cry...

CLINICIAN: And?

CYNTHIA: I cried ... I was scared by yelling and stuff, while they were able to talk and not to cry... they said not to cry...

CLINICIAN: Did your brother have a protective attitude toward you?

CYNTHIA: Well... I have always seen them as allies with each other and distant from me, but surely in these kinds of situation they protected me; our parents' fights made us unite... because if someone was scared, we pulled together, if we were going to say something or we wanted to interfere, we decided to interfere together.

CLINICIAN: What did happen when your parents fought, what scared you?

CYNTHIA: I guess...yelling, their tone of voices changed, my mom's eyes changed color... they changed color...

CLINICIAN: So?

CYNTHIA: When she is mad, she changes her look...

CLINICIAN: Why did they fight?

CYNTHIA: I have no idea. In reality... there were no reasons... they were all crises which were born from skirmishes, so...from nothing... and then repressed anger that they could unload ...

CLINICIAN: And what did they usually do in this case? How did they try to put it right? CYNTHIA: They separated...distance...

CLINICIAN: So they separated awhile... each in different places...

CYNTHIA: ...Different. One of them took the car... but I never saw any attempts to return to their arguments ... they acted as if nothing had happened and they sulked for awhile or sometimes... the day after... as if nothing had happened

CLINICIAN: And so?

CYNTHIA: Nothing... [Segment 2 - end] 


\section{APPENDIX 3: THE 24 AUTOBIOGRAPHICAL MEMORY NARRATIVES, p. 2}

2. [tense change - Segment 34 - mother's anger in CYNTHIA's childhood]

CLINICIAN: Even when you were a child?

CYNTHIA: No, no, when I was a child... because of her own mother instinct which is also very strong... children have been the point of her life... overprotected... I haven't any other traumatic memories...

CLINICIAN: Do you remember her as a loving mother?

CYNTHIA: Yeah, loving, pretty present... however... you know sometime ambiguous from the social point of view that I couldn't understand... because she didn't want to meet people, to do stuff like that...

CLINICIAN: Did she help you in school homework?

CYNTHIA: Yes, yes, yes, she tried... not so much but she was there... available...

CLINICIAN: How did she deal with your school difficulties? If you had problems...

CYNTHIA: Well... I seem to never have had problems at school, but you know... if I told about my problems, she usually believed more that it would depend on a real external cause than a tall story or something I had created by myself...

CLINICIAN: Such as?

CYNTHIA: Perhaps I told her that a teacher was maltreating me at school or something like that... she didn't think that it was my fault... No, immediately she went to the teacher with anger in her voice... and you know she put trust in me... [shift- end Segment 34]

3. CLINICIAN: [tense change- segment 2- Symptoms Past] Has it ever happened before in the past?

CYNTHIA: Yes, yes, but perhaps I was always with somebody and I have never faced problems completely alone...

CLINICIAN: So when did it happen in the past?

CYNTHIA: Perhaps in the class, but it was a sort of anxiety because of staying in different places where I had to talk or... Yes, for example, sometimes even going to a store... sometimes it happened: "Oh, my God! I had to purchase cigarettes and just because of these I became... I felt fearful.. but now it's increased a lot because before I hadn't been in many different social contexts ... now I'm living in Milan ... anyway... everything is different ... I am more completely alone... so (pause) [shift- end Segment 2]

\section{4. [tense change- Segment 5 - Motive present]}

CYNTHIA: I want to enjoy my independence in Milan, but also I don't like to be with people without a sense of mutual understanding and esteem. I usually wouldn't call someone I didn't really like just to have some company. I agree with the idea "better alone than with someone who is not good company," but this idea makes me more isolated. So I don't want to call someone, but I would like to go out alone without feeling any concerns...

CLINICIAN: I know... so these concerns made you ask for help here...?

CYNTHIA: Yes [shift- end Segment 5] 


\section{APPENDIX 3: THE 24 AUTOBIOGRAPHICAL MEMORY NARRATIVES, p. 3}

\section{5. [theme change - Segment 13 - mother grandmother] [Segment 13]}

CYNTHIA: Maria, my mother's grandmother, was a weird character in the family because...well, she was an old-style countess with overly romantic stories. She made me long for and dream about her tales of carriages and noble parties. It was really another time period - the old days she recalled, but her relationship with me was distant...we played cards, other games, but she never touched me, never showed any real human feelings, just many stories.

CLINICIAN: Say more....

CYNTHIA: Perhaps she came from another era, another time, another context. She needed to tell us all that stuff. Anyway, her stories were really interesting, even though I was just a child.

[shift- end Segment 13 ]

6. [theme change - Segment 15- family effects]

CLINICIAN: So, you have lived in a romantic family...

CYNTHIA... In fact.... it has weighed on me... because you know... for example... when I was at the middle school in this small town children called me "little countess" ...missing real contact with other children, with the real world... we have had this huge house and it was so isolated from the other homes. I couldn't go out with other peers, or just play with the neighbors, the way the other kids usually did every day. Then there was all this pressure about family memories and stories - all the old stuff around me, stories about events they told me that... are like dreams to me. I have never been able to live these things; I have never lived them, but I have to remember them. [shift- end Segment 15]

7. [theme change - Segment 20 - mother's jealousy] CLINICIAN: [Did your mother feel] jealousy toward your mother's sister?

CYNTHIA: Yes... They have refused to talk for years and years.

CLINICIAN: For that long! Do you have a memory of this?

CYNTHIA: They had a brief period of reconciliation and that ended about two years ago. However, since I was a child I have never seen... so it's hard for me to remember; we haven't had any contact; we have lived close, but...

CLINICIAN: Side by side?

CYNTHIA: Yes, yes, yes, but so separated.

CLINICIAN: I know. [shift- end Segment 20]

8. [theme change - Segment 23 - event]

CYNTHIA: I know they have fought and they have refused to talk to each other... but they have never told me why .... An actual reason, you know... and when they reconciled three years ago, they brought it up again because some stories came to the surface ... and you know I finally understood what was happening, and what they were talking about...

CLINICIAN: Had you heard their fights?

CYNTHIA: I heard my mother yelling "I was raped... and I had nothing to do with it" ... I believe that my aunt was claiming that my mom had seduced her husband...

CLINICIAN: Do you believe that? Or did someone tell you about that?

CYNTHIA: I don't know... because my mom tried to defend herself from these kinds of accusations... so, anyway... the fact that nobody has ever talked to me about this stuff... it doesn't seem... so clear... why my mother has never told me about... 


\section{APPENDIX 3: THE 24 AUTOBIOGRAPHICAL MEMORY NARRATIVES, p. 4}

CLINICIAN: Have you looked into it yourself or have you asked your sister...?

CYNTHIA: No, I asked her what she knew and slowly she told me that she had heard these stories and tried to put the pieces of what she had heard together. [shift- end Segment 23]

9. [theme change - Segment 25 - mother's events]

CLINICIAN: Do you think any other stories are hidden under the dust, as the saying goes?

CYNTHIA: Other stories... well, my dad... when I was a child and they fought and... my mom was brought to a boarding school and it seems that she broke a nun's leg and... so... I don't know... anyway my mom has clear nervous troubles and so... when my dad wants to make her mad and crazy he usually tells about this story and stuff like that...

CLINICIAN: When your dad wants to make her mad...

CYNTHIA: Yes, anyway... I think it's wrong... either you talk with me about that and we can share these concerns or you give me just more to worry about...

CLINICIAN: So did your mom go to a boarding school?

CYNTHIA: Yes... on her own volition... because... she went to the "classical" high school for one year and then they were going to reject her ... and she wanted to be rejected... and so she gifted a bottle of wine to a professor in order to be rejected and so she could go to the boarding school... but you know she went to a boarding school in Cortina (famous and amazing mountain holiday resort) ... you know... not in a bad town! She usually went skiing every day ... but it was a only female boarding school... just girls and nuns...

CLINICIAN: I can't understand this event about the wine...

CYNTHIA: She corrupted the professor to get him to kick her out ... stuff like that.

CLINICIAN: To be rejected?

CYNTHIA: Yeah, because she just wanted to be skiing and so. As she usually tells this story...

CLINICIAN: How long did she stay there at this school?

CYNTHIA: All her high school period....

CLINICIAN: And then...?

CYNTHIA: She came back home... and she started an Education Major at the university... it makes me laugh... The best teacher in the world!!! And so... she met my aunt...the aunt who lives here in Milan...

CLINICIAN: Your dad's sister...

CYNTHIA: Yes... and now she is refusing to talk even with her...

CLINICIAN: Sorry, could you tell me her name?

CYNTHIA: Giulia

CLINICIAN: so... she meets this aunt, they become friends...

CYNTHIA: Yeah... they live together for almost two years ... I believe.

CYNTHIA: My aunt introduced my dad to my mom... and anyway... now they're refusing to talk to each other, so... my mom decided to stop any contact... when she is not in the mood... she cuts... she cancels... [shift- end Segment 25]

10. [theme change - Segment 26 - mother's breaking]

CLINICIAN: When did they stop? 


\section{APPENDIX 3: THE 24 AUTOBIOGRAPHICAL MEMORY NARRATIVES, p. 5}

CYNTHIA: Well... five years ago... from being together everyday... all family holidays...to nothing.

CLINICIAN: Did your mom stop?

CYNTHIA: Yeah

CLINICIAN: Why?

CYNTHIA: The official motive was that she was annoyed because sometimes during the summer my aunt usually visited us and... you know... a furniture out-of-place... the common swimming pool...you know no relevant stuff... She even usually says that she hasn't a real motive... she just wanted to break it off... even with the other sister of my dad... Marinella... you know the official motive was "she is too similar to your dad"... she is able to say these kind of things in front of me without any kinds of concern... quite clear. I'm losing the train of thought...

CLINICIAN: ...Well, we are talking about your mom's tendency to stop any kind of relationships...

CYNTHIA: Yeah... a lot [shift- end Segment 26]

\section{1. [tense change - Segment 31 - mother's problem]}

CYNTHIA: She has somatized a lot of things... For example she will say "Ah, today I feel a stomach ache," but thinking seriously about this, I guess they were all excuses just because of her desire to escape, to isolate herself and have a way to justify herself in front of others... just to justify her being upset... even if she said she had her period, she could justify herself ... anyway I guess... they are all ways to pass off her troubles inside...

CLINICIAN: Has she never been seen by anyone?

CYNTHIA: Oh no... my God! Not even dentists or gynecologists... you know... a psychologist? She would never see anyone who might catch the slightest hint of her craziness... [shift- end Segment 31]

\section{2. [shift- end Segment 35]}

CLINICIAN: And then how did your relationship change ... ? How did it change from a lovely mother and then, you know?

CYNTHIA: I don't know, it has changed, even if now as for love... when I can cover all the bad just for 5 minutes I usually think about her, the love... expressions or a small sign... but surely at a certain point she has felt alone, not supported by us, she has felt abandoned... it has been a slow and progressive process because bad situations have been increasing and more... I would want to talk with her but I don't find any chances for really talking to her... CLINICIAN: When did your relationship worsen?

CYNTHIA:... The real crisis and traumatic moment came five years ago... My parents had a severe rift...frequent fights; they talked about divorce. My father rented a flat and in one of these fights she saw that her children were opposed to her. They tried to explain where they saw her at fault, but I don't know that she could see this. I don't think she understood that we would not support everything she did just because she was our mother. We were able to think for ourselves. And so - Betrayal! ... My relationship with her has never had a major crisis, but 


\section{APPENDIX 3: THE 24 AUTOBIOGRAPHICAL MEMORY NARRATIVES, p. 6}

slowly I have been feeling more alone and have closed myself off from anything to do with her no interaction and no contact.

[shift- end Segment 35]

13. [tense change - Segment 36 - mother's relationship during teenage]

CLINICIAN: Did you have any dialogue during high school?

CYNTHIA: No, she'd ask me about school and something... but a few words, but I knew that she couldn't understand me ... she had grown up in an absurd way; she was isolated all her life... [shift- end Segment 36]

\section{4. [theme change - Segment 38 - father's grandmother]}

CLINICIAN: And your father's grandmother?

CYNTHIA : I remember and believe that she was died in 1994. She was a "nanny" person... and educational, but always in a funny way, playing ... she taught me a lot of things with clear and simple methods... I don't know... she was a warm person... I liked her.

CLINICIAN: Did you stay with her?

CYNTHIA : Yes, yes, until she died... She had a good relation with my mom ..

CLINICIAN: How did she have a good relationship? different from other relationships...?

CYNTHIA : I don't know. I believe my grandmother was so clear and calm... that she was able to interact without any kind of fights...

CLINICIAN: However your mom with her mom...

CYNTHIA : Well, I don't know ... I don't have any information...

CLINICIAN: And so your dad had a good relationship with his mom...

CYNTHIA : Yes, I think so. I don't have so much data, but he told that his mom was always present, warm and I know ... I could see that she was warm... She looked like a person who had achieved contentment and completeness... and who was doing everything happily. [shiftend Segment 38]

15. [tense change - Segment 43 - mother's grandmother in CYNTHIA's childhood]

CYNTHIA: A very important thing that I remember about my mother's grandmother is that they made me kiss her, even though I did not want to - "Kiss your grandma!" you know... and I said "Why should I? Why do I have to make such a big deal? I want to play..." ... They made me ... unwillingly. [shift- end Segment 43]

16. [theme and tense - Segment 49 - relationship with the father during CYNTHIA's childhood] CLINICIAN: What about your dad when you were a child? What was he like with you?

CYNTHIA: Funny. However, normal...you know. I always use this word with him... playful, present...

CLINICIAN: What about discipline? Upbringing?

CYNTHIA: Well... both my parents kept their children's education in high esteem ... but they weren't violent or oppressive... you know... he was authoritarian, but also easy and...

CLINICIAN: Both authoritarian and easy?

CYNTHIA: They don't go together? 


\section{APPENDIX 3: THE 24 AUTOBIOGRAPHICAL MEMORY NARRATIVES, p. 7}

CLINICIAN: Well, you know they sound...

CYNTHIA: No, in the sense that he wanted to manage us, but we were able to make him relax. CLINICIAN: Could you find an adjective to describe your dad?

CYNTHIA: Even. How can I ...

CLINICIAN: Can you give an example?

CYNTHIA: He always uses the same routines for all situations and stuff... also in even more multifaceted situations... but anyway... it's hard for him to understand other choices or goals apart from his...

CLINICIAN: Any examples? When you were a child... and you know you did a prank... what did your parents do?

CYNTHIA: They scolded me.

CLINICIAN: How?

CYNTHIA: Yelling.

CLINICIAN: Both of them? In the same way?

CYNTHIA: Yes... almost... Perhaps my mom was a little more dramatic... She yelled more than my dad, but you know she was more at home... My father worked and he wanted to be more even-tempered when he stayed with us. And so.[shift- end Segment 49]

17. [Segment 56 - beginning- example of fight]

CLINICIAN: Any other critical periods before the five years ago?

CYNTHIA : No, this was the worst ...

CLINICIAN: Five years ago dad went away...

CYNTHIA : Yes just for a bit... and also my sister was chased away...

CLINICIAN: Did she choose to go with you father?

CYNTHIA : No, my mom chased her away...

CLINICIAN: Do you remember the cause? How did it happen?

CYNTHIA : No, just how it finished... with all my mom's insults because she became a monster... my mom saying all kinds of things [Segment 56 - end]

\section{8. [Segment 60 - beginning]}

CLINICIAN: Did you have any toys at home?

CYNTHIA: Yes we had a place...so we usually played more with our own imagination and we had a huge garden ... [Segment $60-$ end]

19. [Segment 61 - beginning- elementary school]

CLINICIAN: Instead...could you tell me something about the transition between nursery school and elementary school?

CYNTHIA: Well...quite...more people, peers...I was happy, I liked going to the nursery school a lot... at the primary level you realize that you have more to do... you are older and more like others perhaps...

CLINICIAN: Have you any memories? 


\section{APPENDIX 3: THE 24 AUTOBIOGRAPHICAL MEMORY NARRATIVES, p. 8}

CYNTHIA: I liked knowing new people... and then a black hole. I didn't want to go to school...I warmed up a thermometer over a light bulb and my mother after awhile... after many physical examinations sent me to a psychologist...but I didn't want to go school...perhaps it was due to having a too strict teacher... who didn't fit the image of a teacher that I held inside, someone easier, but I think that shouldn't warrant... it wasn't a valid reason to pretend to be sick... and my mother never knew the truth.

[Segment $61-$ end]

\section{0. [Segment 62- beginning -psychologist]}

CLINICIAN: Do you remember the psychologist who saw you?

CYNTHIA: Yes

CLINICIAN: And?

CYNTHIA: He made me play "memory." I liked it... but I didn't know... I remember that at the beginning when my mom said to me in a very sensible way... you know... she explained me that she wanted to ensure that I wouldn't have any mental problems...I broke down and cried 'I'm not crazy!

CLINICIAN: How old were you?

CYNTHIA: Well... 7/8 years old ... second or third school year...

CLINICIAN: What did your mom explain to you?

CYNTHIA: She told me, "Well since you are sick, I'll send you to a doctor of the mind," something like that and I told her, "I'm not crazy! Leave me alone!" and I thought, 'My God, just for a thermometer!' I was scared."

CLINICIAN: Then the situation improved because of... did you go to school again?

CYNTHIA: Perhaps she realized that I was faking... probably I wanted...

CLINICIAN: You created...

CYNTHIA: A little bit of racket...

CLINICIAN: Chaos...

CYNTHIA: I don't remember any more what psychologist said at the end ... now I would be curious to know...

CLINICIAN: What he said at that time? [Segment $62-$ end]

21. [Segment 71 - beginning - high school choice]

CLINICIAN: So you decided for high school to focus on the humanities. Why?

CYNTHIA: I don't know... but I was angry... When I was a child I wanted to paint, I wanted to attend the art secondary school. But I remember a day one afternoon one of my cousins, 11 years older than me, and his friend I felt in love with ... they tried to talk me into going to the school that focused on humanities, and I believed in their ideas within a few minutes in a passive way... They said, "Look at the classical school! It's better for you! You could study with us..."

CLINICIAN: Your cousin and his friend?

CYNTHIA: Yes, yes, and in just a few hours they convinced me... by telling me about reasons why and friends and things to do at school... and I forgot all my ideas ... and expectations and all my will and so on... I remember in the evening at the dinner time I insisted on this to my 


\section{APPENDIX 3: THE 24 AUTOBIOGRAPHICAL MEMORY NARRATIVES, p. 9}

mom who disagreed because it was the same school that had rejected her after her first year... but at the end over the pasta dish I was able to make her believe that I was confident in my decision. [Segment $71-$ end]

22. [Segment 72 - beginning - high school]

CLINICIAN: What about this school?

CYNTHIA: This school.. a drag. Nothing in common with schoolmates... people... apart from them... we were all isolated from the each other... the first year you know... disoriented... I don't know... and then I came from a town background where there was a sort of folklore... and you know... I felt more lively... and in fact I joined with a rebellious girl who hung out with me all the time that year... we skipped school together and then I didn't see her any more ... it was not a real friendship... it was just killing time together because we couldn't breathe there... CLINICIAN: And your parents? What did they think about your changing?

CYNTHIA: Why? Which changing?

CLINICIAN: Well... you described yourself as a quiet, peaceful school girl... and then at the high school...

CYNTHIA: Well no... at school teachers said that I was that way again... the highest level of rebellion was writing graffiti everywhere... or drawing everywhere... and from the educational point of view it was less clear because ...the first six months [at high school] everything went well. I studied; I wanted it to go well. I was motivated. Then the teacher...was replaced. I lost this person whom I liked a lot and I let everything go bad. Only at the end I raced to improve some of my grades to try to finish well. ...I also was not satisfied with my relationships. I had expected that going to school in a bigger city would be better. And it was always the same, the small town girl in a city, studying something that I didn't understand and then when my teacher left...I remember all the endless afternoons in front of the T.V., eating chips. It was terrible. I was trying to lobotomize myself, anything not to study.

CLINICIAN: And mom and dad? Did they realize?

CYNTHIA: Well...I have never had them get involved in my troubles... I don't know if I locked them out or if they didn't press me enough or they didn't ask... and then the fact that I had done well at school before so they knew that I was able to do well ... and they didn't see it as a tragedy ... Well, my dad did more... However, compared to my brother who had done very badly at school and my sister who had been very brilliant ... well I was average [Segment 72 end]

23. [Segment 73 - beginning - change of high school]

CLINICIAN: And then ...

CYNTHIA : Dramatic change, I chose a high school for the arts ... Wow! Wonderful .... public school. I remember that I was miserable at the end of the first year of the classical school, because I wanted to be rejected and then I wanted to start again at the art school...

CLINICIAN: Had you chosen to transfer to the art school before the end of the year?

CYNTHIA : Yes. I had decided before I finished school... because I felt I would need a change. And then all these paintings ... [Segment 73 - end] 


\section{APPENDIX 3: THE 24 AUTOBIOGRAPHICAL MEMORY NARRATIVES, p. 10}

[Segment 74 - beginning - artistic attitude]

CLINICIAN: What did you paint usually? When did you discover your artistic tendencies?

CYNTHIA : I don't know... I remember at the nursery school that I hid the paintings that I didn't like in order to have a new white sheet, and they found all my bad paintings. I don't know... probably I liked to create something new...from white to black. I don't know - a sort of fascination... Then I was under a spell of painters...

CLINICIAN: Painters?

CYNTHIA : Yes, I felt all painters, writers and musicians were clever people... Actually I know that doing beautiful things does not mean that you are... but I created all this mythology...

CLINICIAN: That it might?

CYNTHIA : Yes [Segment $74-$ end]

24. [Segment 75 - beginning - high school change]

CLINICIAN: However at the end you were not rejected and so you transferred to the art school automatically in the second year...

CYNTHIA : Yes.

CLINICIAN: It was a private school ... your parent's choice?

CYNTHIA : I wanted to do a public school but I didn't pass the exams... because I remember that they gave me the wrong date for the exam and... I don't know... I didn't pass the exam...

CLINICIAN: So?

CYNTHIA : My mom fought by phone against the head because they made a mistake and I was desperate... and so at the end they decided for a private school without any kind of exam or requirement... [Segment 75 - end] 